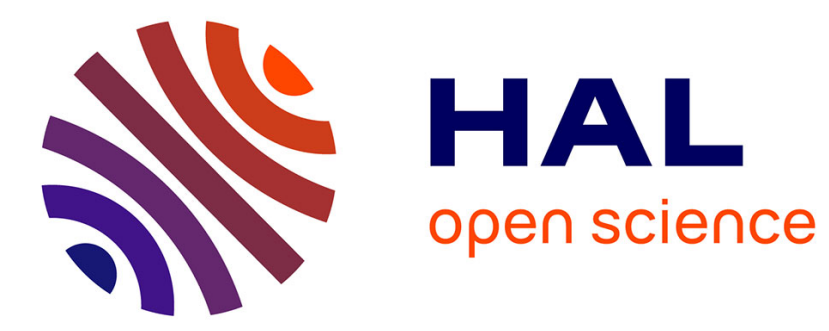

\title{
Elastic thickness control of lateral dyke intrusion at mid-ocean ridges
}

Raphael Grandin, Anne Socquet, Cécile Doubre, Eric Jacques, Geoffrey C.P.

King

\section{- To cite this version:}

Raphael Grandin, Anne Socquet, Cécile Doubre, Eric Jacques, Geoffrey C.P. King. Elastic thickness control of lateral dyke intrusion at mid-ocean ridges. Earth and Planetary Science Letters, 2012, 319-320, pp.83 - 95. 10.1016/j.epsl.2011.12.011 . hal-01621444

\section{HAL Id: hal-01621444 \\ https://hal.science/hal-01621444}

Submitted on 23 Oct 2017

HAL is a multi-disciplinary open access archive for the deposit and dissemination of scientific research documents, whether they are published or not. The documents may come from teaching and research institutions in France or abroad, or from public or private research centers.
L'archive ouverte pluridisciplinaire HAL, est destinée au dépôt et à la diffusion de documents scientifiques de niveau recherche, publiés ou non, émanant des établissements d'enseignement et de recherche français ou étrangers, des laboratoires publics ou privés. 


\title{
Elastic thickness control of lateral dyke intrusion at mid-ocean ridges
}

\author{
Raphaël Grandin ${ }^{a}{ }^{\text {** }}$, Anne Socquet ${ }^{\text {b }}$, Cécile Doubre ${ }^{c}$, Eric Jacques ${ }^{d}$, Geoffrey C.P. King ${ }^{\text {d }}$ \\ a Ecole Normale Supérieure, Paris, France \\ b Institut des Sciences de la Terre, Grenoble, France \\ c Institut de Physique du Globe de Strasbourg, France \\ d Institut de Physique du Globe de Paris, France
}

\section{A R T I C L E I N F O}

\section{Article history:}

Received 19 July 2011

Received in revised form 20 November 2011

Accepted 8 December 2011

Available online $\mathrm{xxxx}$

Editor: Y. Ricard

\section{Keywords:}

mid-ocean ridge

dyke intrusion

mechanics of the lithosphere

\begin{abstract}
A B S T R A C T
Magmatic accretion at slow-spreading mid-ocean ridges exhibits specific features. Although magma supply is focused at the centre of second-order segments, melts are episodically distributed along the rift toward segment ends by lateral dyke intrusions. It has been previously suggested that an along-axis downward topographic slope away from the magma source is sufficient to explain lateral dyke propagation. However, this cannot account for the poor correlation between dyke opening and surface elevation in the 2005-2010 series of 14 dyke intrusions of Afar (Ethiopia). Using mechanical arguments, constrained by both geodetic and seismological observations, we propose that the large dykes that initiate near the mid-segment magma source are attracted toward segment ends as a result of a thickening of the elastic-brittle lithosphere in the along-rift direction. This attraction arises from the difference of elastic resistance between the segment centre where the lithosphere is thermally weakened by long-term focusing of melts, and comparatively "colder", hence stronger segment ends. The axial topographic gradient in magmatic rifts may be more likely explained as an incidental consequence of these variations of along-axis elastic-brittle thickness, rather than the primary cause of lateral dyke injections.
\end{abstract}

(c) 2011 Elsevier B.V. All rights reserved.

\section{Introduction}

Vertical ascent of magma through the lithosphere is a widespread observation in volcanic regions around the world, and is generally explained by the buoyancy of molten rock with respect to solid host-rock (e.g. Weertman, 1971). A more intriguing phenomenon is the horizontal migration of magma during a lateral dyke intrusion. Because lateral dyke intrusions are suspected to be ubiquitous at mid-ocean ridges (MOR) (Dziak et al., 2004; Smith and Cann, 1999), a better understanding of the conditions driving horizontal magma migration is required to assist interpretations of accretion processes in terms of an evolution of melt supply to the ridge (Buck et al., 2005; Rabain et al., 2001).

So far, the most complete set of evidence of lateral dyke intrusions originates from studies of the only two sub-aerial sectors of the MOR system, namely Iceland and Afar. These two hotspot-influenced regions represent two different stages of oceanisation: mature in Iceland, incipient in Afar. The Krafla (Iceland, 1975-1984) and Manda Hararo (Afar, Ethiopia, 2005-2010) rifting episodes consisted in major periods of magmatic unrest, during which 21 and 14 dykes, respectively, were intruded along the rift zones, involving cumulative

\footnotetext{
* Corresponding author.

E-mail address: grandin@geologie.ens.fr (R. Grandin).
}

volumes of magma of the order of $1-3 \mathrm{~km}^{3}$ (e.g. Björnsson, 1985; Grandin et al., 2010b). Seismic activity coeval with dyke tip propagation has shown that several, if not all, dykes during these rifting episodes have migrated horizontally at velocities of $\sim 1 \mathrm{~km} / \mathrm{h}$ away from a single mid-segment magma reservoir (Fig. 1) (Belachew et al., 2011; Brandsdóttir and Einarsson, 1979; Grandin et al., 2011; Keir et al., 2009). In both cases, the first dyke of the sequence was the largest in volume and migrated over the longest distance: up to $2 \mathrm{~km}^{3}$ and 30-35 km at Manda Hararo (Ayele et al., 2009; Grandin et al., 2009) and $0.15 \mathrm{~km}^{3}$ and $60 \mathrm{~km}$ at Krafla (Björnsson, 1985). Subsequent dyke intrusions propagated unidirectionally. They appear to be organised in sub-sequences, with (1) the same direction of propagation and decreasing distance of propagation within a single sub-sequence, and (2) a shift in direction between successive sub-sequences (Buck et al., 2006; Grandin et al., 2010b; Hamling et al., 2009). An increase of eruptive activity and a coeval decrease of the rate of magma intrusion are observed throughout the duration of a rifting episode (Björnsson, 1985; Ferguson et al., 2010; Grandin et al., 2010b).

Several models have attempted to explain lateral dyke intrusions. The common view is that melts first experience a buoyancy-driven vertical ascent through the lithosphere, and then stop ascending at a certain depth level, where their trajectories become horizontal. This change of propagation direction (vertical, followed by horizontal) is believed to occur at a critical level that either represents a level of neutral buoyancy (LNB), defined as the depth above which lithospheric 


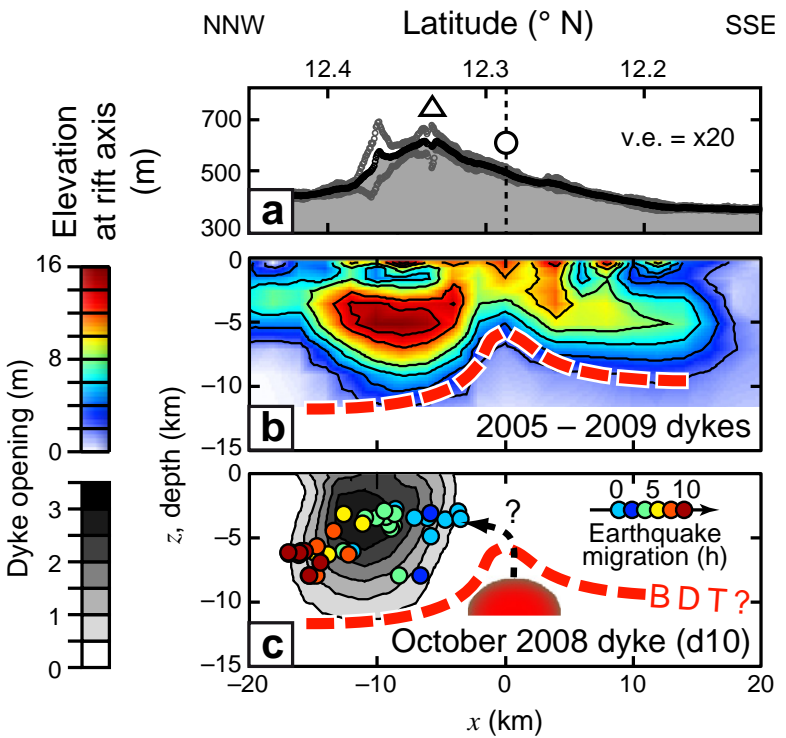

Fig. 1. (a) Surface elevation along the axis of the Manda Hararo-Dabbahu rift (Afar, Ethiopia). The black curve is the elevation averaged in a $5 \mathrm{~km}$ wide sliding cross-section centred on the rift axis, and the grey curves show the maximum dispersion of elevations in this sliding region (vertical exaggeration: $\times 20$ ). The white circle indicates the location of the source reservoir, which is offset by $\sim 7 \mathrm{~km}$ to the SSE with respect to the summit of the axial depression, whose location is indicated by the white triangle. (b) Distribution of cumulative opening between September 2005 and June 2009 as a result of intrusion of 13 dykes along the Manda Hararo rift, deduced from inversion of InSAR data. $x$ is the horizontal distance along the rift, with origin at the central magma reservoir. Red dashed line shows depth of the brittle-ductile transition (BDT), inferred from depth of maximum dyke opening for the 2005-2009 dykes (vertical exaggeration: $\times 1$ ). Note the poor correlation between dyke opening and surface elevation (Grandin et al., 2010a,b). (c) Opening distribution for October 2008 dyke (d10). Location of the source reservoir (shown schematically as a red sphere) has been inferred from inflation/deflation cycles imaged by InSAR during the 2005-2010 rifting episode (Grandin et al., 2010a; Hamling et al., 2009, 2010). Circles indicate the migration of earthquake activity coeval to dyke emplacement (Grandin et al., 2011). Earthquakes are colour-coded as a function of origin time. Although earthquake depths are poorly constrained, the lateral migration of seismicity shown here is typical of other intrusion events in the 2005-2010 rifting episode (Belachew et al., 2011; Grandin et al., 2011; Keir et al., 2009). (For interpretation of the references to colour in this figure legend, the reader is referred to the web version of this article.)

rocks become less dense than liquid magma (Lister and Kerr, 1991; Ryan, 1993), or the brittle-ductile transition (BDT) where tectonic extension is maximum (Rubin and Pollard, 1987), or a combination. In either scenario, lateral dyke intrusion occurs as a result of magma spreading along an equilibrium interface because the dyke cannot expand in the vertical direction. If the interface is flat, the model predicts that maximum dyke opening should be observed directly above the locus of melt supply (Lister and Kerr, 1991). However, the maximum thickness of most dykes intruded in the Krafla and Manda Hararo rifts was offset from the mid-segment magma source by $10-30 \mathrm{~km}$, with little dyke opening observed in the vicinity of the source (Fig. 1b) (Björnsson, 1985; Grandin et al., 2010b). Explaining this striking observation requires a mechanism capable of efficiently attracting dykes laterally away from the source reservoir.

An extension of the above interpretation states that the commonly observed decrease of along-axis elevation toward segment ends constitutes the primary cause for the lateral propagation of dykes. The proposed reason for horizontal magma migration is the tendency of magma to flow under its own weight along a sloping level located at constant vertical distance below the sloping Earth's surface (Rubin and Pollard, 1987) (blue line in Fig. 2). This model has been put forward to explain lateral dyke propagation from a reservoir located beneath shield volcanoes radially (Pinel and Jaupart, 2004) or along the rift zone direction (Buck et al., 2006; Fialko and Rubin, 1998). However, this "sloping surface model" fails to explain the

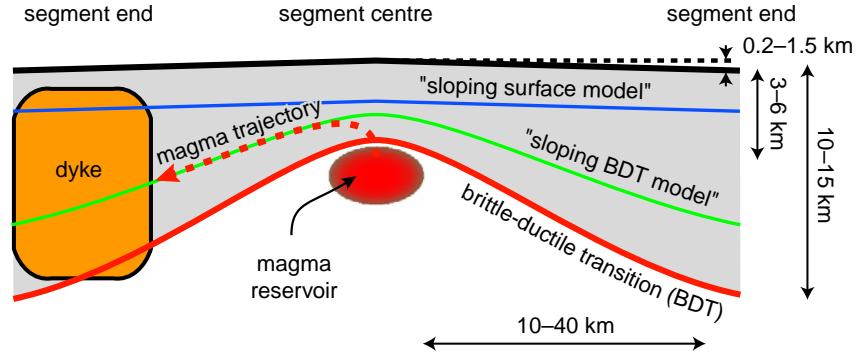

Fig. 2. Along-axis cross-section of an idealised magmatic segment showing deepening of the brittle-ductile transition (BDT, red line) and shallowing of surface elevation (black line) toward segment ends. Magma injected from a mid-segment reservoir (red ellipse) migrates laterally toward one segment end (red dashed arrow), either at a constant vertical distance below surface topography ("sloping surface model", blue line) or following a trajectory parallel to the BDT ("sloping BDT model", green line). Values of depth and distance on the right and bottom are indicative of the typical range found in nature. (For interpretation of the references to colour in this figure legend, the reader is referred to the web version of this article.)

recent observation of a poor correlation between surface elevation and dyke opening during the Manda Hararo rifting episode (Grandin et al., 2009, 2010b). Indeed, maximum cumulative dyke opening between 2005 and $2010(\sim 15 \mathrm{~m})$, which has occurred $\sim 10 \mathrm{~km}$ north of the central magma reservoir, is located below the site of maximum elevation (400-650 m), whereas lower elevations (300-400 m) correspond to less opening ( 8 m) (Grandin et al., 2010b) (Fig. 1a-b). The source reservoir itself, which corresponds to a local minimum of dyke opening and dyke height, is located below a site of intermediate elevation $(\sim 500 \mathrm{~m})$.

In this paper, we alternatively propose that lateral dyke injections are driven by an along-axis increase of the elastic-brittle thickness (or, in other words, a deepening of the BDT) away from the segment centre toward segment ends. Indeed, a greater elastic-brittle thickness toward segment ends means that more elastic potential energy can be stored there, compared to segment centre where magma is injected into a thinner elastic lithosphere. This situation induces a lateral gradient of differential stress that is sufficient to drive dyke injections laterally away from the mid-segment magma source (green line in Fig. 2). The main factor controlling these along-axis variations of elastic-brittle thickness in slow-spreading MORs is likely the thermal structure of the axial lithosphere, which is characterised by a focusing of hot magmatic material at segment centre that thermally weakens the lithosphere and produces comparatively colder, hence stronger segment ends (Chen and Morgan, 1990; Phipps Morgan et al., 1987). Evidence for such variations of strength are established on geophysical observations of the tridimensional structure and segmentation of the MOR lithosphere (e.g. Doubre et al., 2007a; Kong et al., 1992; Kuo and Forsyth, 1988; Lin et al., 1990; MacDonald et al., 1991; Magde et al., 1997), and supported by the thermomechanical models typically employed in attempts to shed light on accretion processes at MORs (e.g. Neumann and Forsyth, 1993; Poliakov and Buck, 1998; Shaw and Lin, 1996; Tapponnier and Francheteau, 1978).

We propose to quantify the effect of variations in the thickness of the elastic-brittle axial lithosphere on dykes propagating laterally, and to compare this effect to that induced by along-axis variations of surface elevation. The paper is organised as follows. First, we review the main factors controlling the phenomenon of dyke intrusion, and highlight the importance of the distribution of stress in controlling the style and depth of dyke intrusions in a vertical section. Then, we compare the efficiency of the two competing models (i.e. sloping topography versus thickening of the elastic-brittle lithosphere) in producing lateral changes of stress conditions that promote horizontal magma migration. Finally, we discuss the implications and limitations of our model. 


\section{Factors controlling the depth of magma intrusion in a vertical section}

\subsection{Definition of the driving pressure}

In the Earth's lithosphere, stresses are generally compressive, and empty voids located deeper than several hundred metres would close rapidly by creep or fracturing of host rock (e.g. Lachenbruch, 1961; McGarr et al., 1979). In contrast, a cavity filled with a pressurised fluid can be stable for a longer time. In a magma-rich extensional tectonic environment, such as at MORs, magmatic fluid emplaces in tensile cracks oriented normal to the direction of the least compressive principal stress $\sigma_{3}$, which is parallel to the direction of plate divergence. Therefore, dykes are vertical and strike normal to the direction of tectonic extension (Anderson, 1938). In the following, we adopt the geologic convention, stating that compressive stress is positive.

The possibility for a dyke to open or close depends on the balance between magma pressure inside the dyke $p_{m}$, which acts to widen the dyke, and the horizontal compressive stress $\sigma_{3}$, which opposes dyke opening (e.g. Pollard et al., 1983; Rubin, 1990) (Fig. 3). The driving pressure $P_{d}$ (sometimes called the driving stress) is a local quantity defined as the difference between these two stress components:

$P_{d}=p_{m}-\sigma_{3}$

Limiting the analysis to the vertical direction, dyke opening should occur primarily in the depth range where $P_{d}>0$ (e.g. Weertman, 1971). However, due to elastic deformation of host-rock, dykes can propagate into regions where $P_{d}<0$, so that dyke intrusions ascending within the lithosphere can overshoot above and below the depth range where $P_{d}>0$ (Fig. 3c). Neglecting these elastic interactions and resistance to fracture of host-rock, the tendency for magma
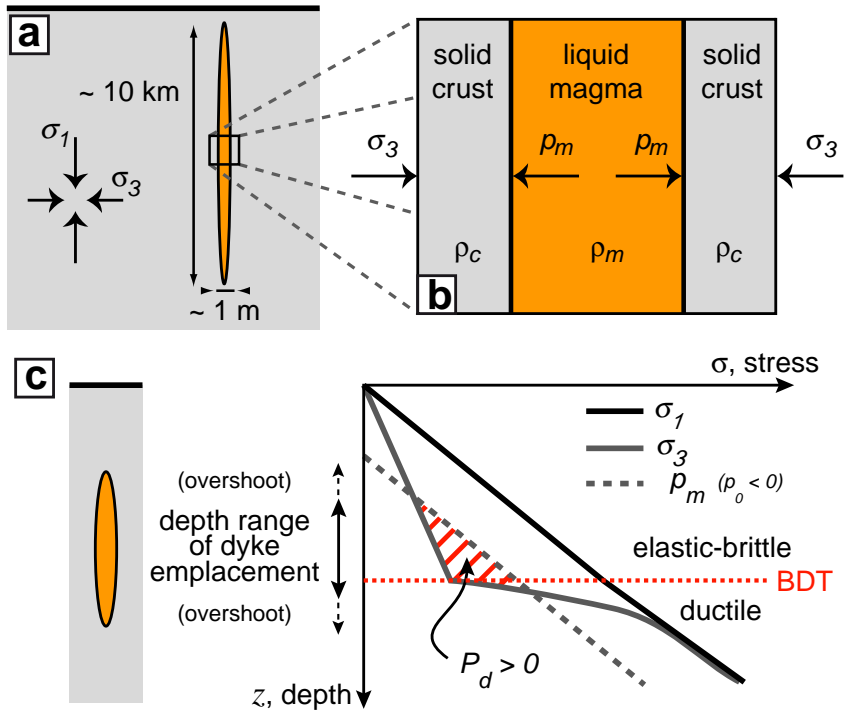

Fig. 3. (a) Cross-section of a dyke intrusion, perpendicular to its along-strike direction (b) Blow-up of the magma-filled dyke, showing the stress components acting normal on the crack surface. Orange: magma (dyke interior). Grey: host rock (dyke exterior). (c) Stress as a function of depth when differential stress $\sigma_{d}$ follows the yield envelope ("faulting stress case"). The magnitude of $\sigma_{d}$ (defined as $\sigma_{d}=\sigma_{3}-\sigma_{1}<0$ ) is minimum (i.e. relative tension is maximum) at the brittle-ductile transition (BDT). The area hatched in red indicates the region of positive driving pressure $P_{d}$, i.e. where magma pressure exceeds the horizontal least compressive principal stress (magma pressure above and below this region is extrapolated). Dyke intrusion preferentially occurs in this depth range, although actual dyke height can be greater due to elastic deformation of host-rock near dyke top and bottom. The cross-sectional shape of the dyke shown here is schematic. Note that the dyke shown here does not reach the surface, which corresponds to a negative magma overpressure $p_{0}$. (For interpretation of the references to colour in this figure legend, the reader is referred to the web version of this article.) ascent, descent or arrest, is captured by the magnitude of $\partial P_{d} / \partial z$, where $z$ is the depth below the surface. Therefore, to understand whether a pocket of magma trapped in the Earth's interior should ascend up to the surface, stop at a certain depth, or descend, we need to derive the expression of $P_{d}$ as a function of depth in a vertical section.

In an extensional tectonic context, the most compressive component of the stress tensor $\left(\sigma_{1}\right)$ is vertical. We assume that the intermediate stress $\sigma_{2}$ (horizontal, parallel to the rift strike) plays no role in the analysis, which is therefore limited to the $\left(\sigma_{1}, \sigma_{3}\right)$ plane. The magnitude of the differential stress $\sigma_{d}$ corresponds to the amount of relative tension in the lithosphere:

$\sigma_{d}=\sigma_{3}-\sigma_{1}$

With the geologic convention, extensional stress conditions imply that $\sigma_{1}>\sigma_{3}>0$, so that $\sigma_{d}<0$ Therefore, $\left|\sigma_{d}\right|$ corresponds to the magnitude of relative tension in the lithosphere. In general, $\sigma_{1}$ is assumed to depend on the burden of overlying rocks, and is called the "lithostatic pressure":

$\sigma_{1}(z)=\rho_{r} g z$

where $\rho_{r}$ is the density of the overlying rocks, assumed constant here, and $z$ is the depth below the surface, i.e. here the height of the overlying rock column. A similar expression is obtained for the pressure distribution in the magma column trapped inside a dyke, using a magma density $\rho_{m}$ :

$p_{m}(z)=\rho_{m} g z+p_{0}$

with $p_{0}$ corresponding to magma overpressure. For the sake of simplicity, we assume that magma overpressure $p_{0}$ is constant during dyke intrusion, i.e. viscous pressure loss contributions to $p_{m}$ are not considered. The main implications of this assumption are qualitatively discussed in Section 4 . We also note that $p_{0}$ can be negative in the case of a magma column trapped at depth.

As discussed later in Section 3, the depth below the free surface $(z)$ and the absolute vertical level referenced with respect to sea level (later noted $Z$ ) should be distinguished in the expressions of the pressure distribution in fluids (e.g. in Eq. 4) if the Earth's surface is not flat. However, in the present section, we focus on the establishment of an expression for the variability of the driving pressure in a vertical section, so we may temporarily use only one notation for the position along the vertical axis $(z)$. Using Eq. (1) and this temporary simplification, we find that the driving pressure includes the contribution of three terms: (1) buoyancy of the magma, caused by the density contrast $\Delta \rho=\rho_{m}-\rho_{r}$ between magma and host rock, (2) differential stress $\sigma_{d}$, i.e. the magnitude of relative tension in the lithosphere, and (3) magma overpressure $p_{0}$ (e.g. Buck, 2006; Fialko and Rubin, 1998; Gudmundsson, 1986; Pollard et al., 1983; Rubin and Pollard, 1987):

$P_{d}(z)=\Delta \rho g z-\sigma_{d}(z)+p_{0}$

As discussed above, the vertical motion of dykes is controlled by the magnitude and sign of $\partial P_{d} / \partial z$. Eq. (5) shows that $\partial P_{d} / \partial z$ depends both on the buoyancy of magma with respect to host rock $(\Delta \rho g)$ and the variation of differential stress as a function of depth $\left(\partial \sigma_{d} / \partial z\right)$. Because lateral dyke intrusions in Afar and Iceland mostly remain trapped below the Earth's surface (Abdallah et al., 1979; Björnsson, 1985; Ferguson et al., 2010; Grandin et al., 2010b), these two contributions necessarily equilibrate each other at a certain depth (i.e. $\partial P_{d} / \partial z=0$ ), as illustrated in Fig. 4 . When tectonic stress is uniformly equal to zero ("lithostatic state of stress"), this may occur if the density of host-rock happens to be lower than that of magma above a certain horizon, so that the sign of $\Delta \rho$ changes, and magma becomes negatively 

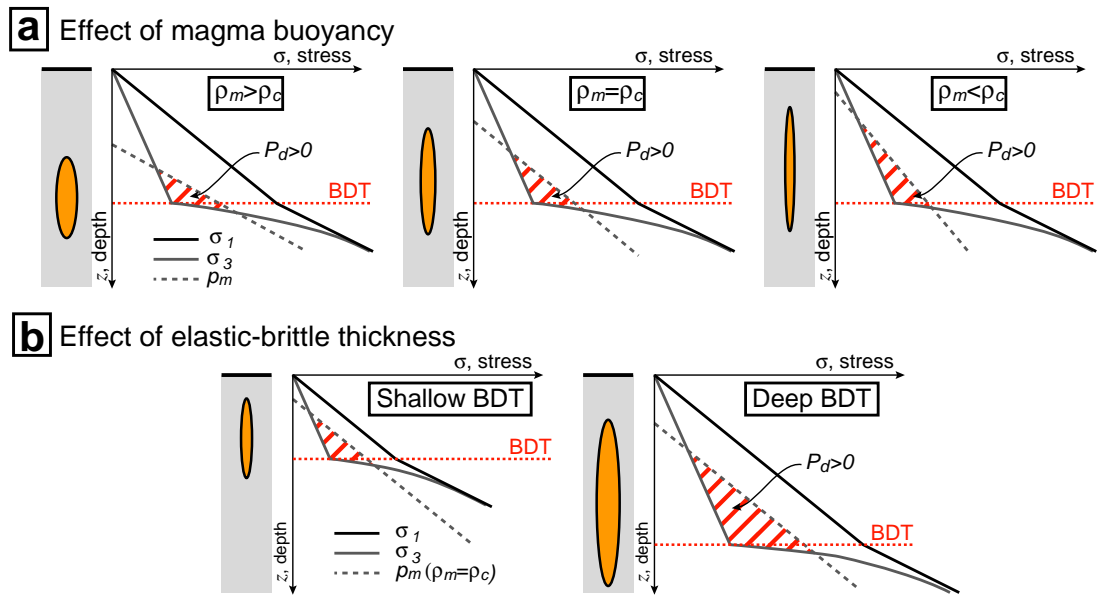

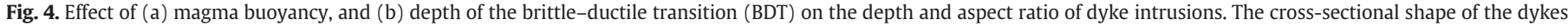
shown here is schematic.

buoyant ("level of neutral buoyancy", LNB (Lister and Kerr, 1991; Ryan, 1993)). However, it can be shown that in the case of a moderate amount of tectonic loading, as is appropriate to describe stress conditions in MORs, changes in the gradient of differential stress $\partial \sigma_{d} / \partial z$ may easily exceed those of $\Delta \rho g$ (see Fialko and Rubin, 1998; Rubin, 1995; Rubin and Pollard, 1987). Therefore, only the expression of $\sigma_{d}(z)$ needs to be derived to identify the preferential depth of emplacement of dykes. This is done in the following sub-section.

\subsection{State of stress in the lithosphere as a function of depth}

In this sub-section, we concentrate our analysis on the determination of the depth of preferential dyke emplacement for a reasonable scenario of the depth distribution of $\sigma_{d}$. For simplicity, we assume that densities $\rho_{r}$ and $\rho_{m}$ are constant and that the effect of buoyancy forces on $\partial P_{d} / \partial z$ may be neglected in comparison to that of tectonic stress (i.e. $\partial P_{d} / \partial z \approx \partial \sigma_{d} / \partial z$ ). In this case, magma emplaces preferentially in the depth range where $\sigma_{d}$ reaches its minimum, i.e. where relative tension is maximum (Fig. 3c).

In a lithostatic state of stress, no differential stress occurs, so that $\sigma_{1}=\sigma_{3}=\rho_{r} g z$ everywhere (Eq. 3 ). This is generally not the case in an active tectonic context, where differential stress accumulates as a result of deformation of the lithosphere (i.e. $\sigma_{d}$ becomes increasingly negative in an extensional context). For small amounts of stretching, strain is stored elastically, in a reversible fashion. As availability of magma seems to control the dynamics of rifting (Buck et al., 2006), if melting below the lithosphere proceeds slowly, stresses can build up to a high level until sufficient magma becomes available to initiate rifting and feed voluminous dykes. In that case, the first dyke to escape the source reservoir preferentially emplaces in the depth interval where tectonic extension is highest (see previous sub-section). Successive dyke intrusions progressively "consume" the elastic potential energy stored within the lithosphere, until (1) magma pressure or (2) tectonic extension have dropped so much that (1) further dyke injections cannot be initiated or (2) magma reaches the surface and is extruded in an eruption.

However, the maximum amount of elastic or recoverable strain that can be stored in the lithosphere is limited by the strength of the lithosphere. In the absence of magma, this limit depends on the resistance to rupture of pre-existing normal faults extending through the brittle lithosphere (e.g. Brace and Kohlstedt, 1980). In the presence of magma, the limit depends on the tensile strength of rocks in the presence of magma-filled dykes, which is much lower (Rubin and Pollard, 1987; Turcotte and Schubert, 2002). Therefore, because the stress distribution prior to onset of a dyke intrusion is controlled by yield criteria associated with normal faulting, the depth interval for dyke intrusions depends on the shape of the yield envelope in the absence of magma, whose expression is derived below.

Brittle rupture associated with faulting occurs when the shear stress $\tau$ resolved on pre-existing normal faults exceeds the resistance to slip on the crack's surface due to friction, which is given by the product of the normal stress $\sigma_{n}$ and the coefficient of static friction $\mu$. Taking into account the additional effect of water pore pressure $p_{w}$, the stability criterion is expressed as:

$|\tau| \leq \mu\left(\sigma_{n}-p_{w}\right)$

where $p_{w}$ is water pore pressure:

$p_{w}=\rho_{w} g z$

with $\rho_{w}$ the density of water (assumed constant here, and equal to $1000 \mathrm{~kg} / \mathrm{m}^{3}$ ). In the above equation, it is implicit that pore pressure is assumed to be nearly hydrostatic (i.e. $p_{w} \sim 0$ near the surface), which is appropriate as long as depth is shallow (less than $10 \mathrm{~km}$ ). In a lithostatic stress state, for any geometry of the fault, $\sigma_{n}$ is the burden stress $\sigma_{1}$ defined in Eq. (3). However, as soon as $\sigma_{1} \neq \sigma_{3}$, then $\sigma_{n}$ also depends on the fault dip $\theta$ and the magnitude of differential stress $\sigma_{d}$ (e.g. Turcotte and Schubert, 2002). Introducing an effective coefficient of friction $A$, Eq. (6) may be rewritten as:

$\sigma_{d} \geq-2 A\left(\rho_{r}-\rho_{w}\right) g z$

with rupture occurring when the equality is satisfied (Byerlee's frictional law) (e.g. Byerlee, 1967). The lithosphere is said to be in a state of incipient faulting at all depths ("faulting stress case") when equality in Eq. (8) is satisfied at all depths. The effective coefficient of friction depends on the coefficient of static friction through the relation:

$A=\frac{\mu}{\sqrt{1+\mu^{2}}+\mu}$.

Fixing the value of $\mu$ allows one to determine the optimal dip of faults $\theta^{\text {opt }}$ for the state of incipient faulting through the relation tan $\left\{2\left(\pi / 2-\theta^{\text {opt }}\right)\right\}=1 / \mu$ which maximises the Coulomb stress (defined as the difference between the shear stress and the coefficient of friction times the normal stress). Then, the dependence of maximum differential stress as a function of depth, via $A$ in Eq. (8), is readily found. For $\mu=0.85$ (condition relevant to depths shallower than $8 \mathrm{~km}$ (Byerlee, 1968), we obtain $\theta^{o p t}=65^{\circ}$ and $A=0.39$. For greater depths, $\mu=0.6$ is appropriate (Byerlee, 1978; Dieterich, 1972), and 
yields $\theta^{\text {opt }}=60.5$ and $A=0.34$. With such values of $A$, and realistic values of lithospheric rock densities $\left(\rho_{r}=2600-3000 \mathrm{~kg} / \mathrm{m}^{3}\right.$, considering that the elastic layer of the lithosphere in such context corresponds to the upper crust), maximum differential stress in the lithosphere increases linearly with depth at a rate of $10-15 \mathrm{MPa} / \mathrm{km}$ (Brace and Kohlstedt, 1980; Rubin, 1992). In other words, comparison of Eqs. (3) and (8) shows that the Byerlee frictional law for a tectonic environment in extension imposes that $\sigma_{1} \geq \sigma_{3} \geq 0.5 \times \sigma_{1}$, which can we rewritten as $-0.5 \times \sigma_{1} \leq \sigma_{d} \leq 0$.

This expression is assumed to hold above the BDT. At greater depth, where temperature is higher, the material cannot sustain high differential stress either, but yield will occur by plastic flow or ductile deformation at lower stress levels than required for brittle faulting or dyking. This behaviour is described by a variety of laboratory-derived rheological laws, which include a dependence upon the strain rate, the temperature (via a Boltzmann exponent), and the nature of the material and its water content (e.g. Brace and Kohlstedt, 1980; Kohlstedt and Goetze, 1974). A major uncertainty arises from applying these laws to large-scale deformation, as well as from imprecise knowledge of conditions (composition, temperature, etc.) at depth. The simplest assumption is to state that the differential stress is bounded by a function of the form (e.g. Poliakov and Buck, 1998):

$0 \geq \sigma_{d} \geq-B \exp \left(\frac{H-z}{H_{c}}\right)$ for $z \geq H$

where $H_{c}$ is the characteristic length scale of the decay of strength at increasing depth. $B$ is a factor controlling the strength of the material. With the previous definition of differential stress in Eq. (8), continuity of $\sigma_{d}(z)$ requires that $B=2 A\left(\rho_{r}-\rho_{w}\right) g H$. This expression implies that differential stress decreases rapidly below a depth $H$, which we assume here to correspond to the depth of the BDT. In the following, the terms "depth of the BDT" and "thickness of the elastic-brittle lithosphere" will be used indistinctively. As a consequence of Eqs. (8) and (10), in the faulting stress case, magma injection will preferentially occur near the depth of the BDT.

\section{Conditions driving dyke intrusion in the horizontal direction}

\subsection{Method}

In this section, building upon the expression of $\partial P_{d} / \partial z$ developed in the previous section, we perform a first-order calculation of the magnitude of the horizontal gradient of driving pressure $\partial P_{d} / \partial x$ for two distinct scenarios that aim at providing an explanation of the phenomenon of lateral dyke intrusions. Magma is assumed to migrate laterally along a downward-sloping equilibrium level, which we assume here to correspond to the BDT. However, the geometric configuration of the free surface with respect to the BDT is different in the two scenarios: in the first scenario ("sloping surface model"), the BDT lies at a constant vertical distance below a sloping topography (blue line in Fig. 2), whereas, in the second scenario ("sloping BDT model"), the free surface need not play a primary role and the slope of the BDT is rather related to the along-axis thermal gradient in the lithosphere (green line in Fig. 2).

We assume that dykes are trapped at the depth where driving pressure is maximum, i.e. at depth $z$ where $\partial P_{d} / \partial z=0$, or $P_{d}=P_{d}^{\max }$. According to the yield criteria described above, for a lithosphere in a state of incipient rupture at all depths ("faulting stress case"), this preferential level lies approximately at the BDT for a wide range of density contrasts between magma and host rock (Fig. 4a). Then, once magma is trapped at that critical depth, the lateral trajectory of magma-filled cracks becomes affected by the magnitude of the lateral gradient of driving pressure $\partial P_{d} / \partial x$ along the BDT, which we relate here to heterogeneity in the horizontal distribution of density and differential stress within the lithosphere due to slopes of the surface topography and BDT. To assess the magnitude of the lateral variations of driving pressure "sensed" by a magma pocket migrating along the BDT, we calculate the variation of the magnitude of the driving pressure $\Delta P_{d}^{\max }$ at the BDT between two points separated by a distance $\Delta x$ along the magmatic rift (Fig. 5). The horizontal gradient of driving pressure is then deduced using the approximate relation:

$\frac{\partial P_{d}}{\partial x} \approx \frac{\Delta P_{d}^{\max }}{\Delta x}$.

Prior to developing a full expression of $\partial P_{d} / \partial x$, we point out that expressions of variations of magma pressure and water pressure as a function of depth (Eqs. (4) and (7) and subsequent dependent equations) require special care. Indeed, taking into account a hydraulic connectivity, magma and water pressures depend on the absolute vertical level $Z$ with respect to a horizontal surface (because fluids cannot sustain a shear stress), whereas lithostatic stress depends on the height of the overlying rock column $z$ (as illustrated in Fig. 5). This hypothesis, for pore pressure $p_{w}$, is equivalent to assuming that water-filled pores are interconnected and in hydrostatic equilibrium with a flat-lying pressure level, for instance sea level (however, $p_{w}$ could be tied to the local surface elevation rather than absolute elevation, with no impact on our conclusions). For magma pressure $p_{m}$, the assumption is equivalent to stating that pressure is transmitted within the magma inside the propagating dyke, which is a major assumption of our model.

Finally, assuming that equality is satisfied in Eq. (8) (i.e. the lithosphere is in a state of incipient faulting at all depths), the following expression for the driving pressure above the BDT is found:

$P_{d}(z, Z)=\rho_{m} g Z-\rho_{r} g z+2 A\left(\rho_{r} g z-\rho_{w} g Z\right)+p_{0}$

where we recall that $z$ is the height of the overlying rock column, and $Z$ is the vertical distance with respect to an arbitrary horizontal reference surface, for instance sea level. $z$ and $Z$ necessarily differ if the Earth's surface is not flat. The changes of $z$ and $Z$ between two sites along the BDT separated by a distance $\Delta x$ are noted $\Delta z$ and $\Delta Z$, respectively (Fig. 5). As a consequence of Eqs. (11) and (12), the quantity $\partial P_{d} / \partial x$ is uniquely determined by geometrical parameters $\Delta z$ and $\Delta Z$. To relate these parameters, we assume that the free surface makes an angle $\alpha$ with the horizontal, and that the BDT makes an angle $\beta$ with the horizontal (Fig. 5a). Let $P_{1}$ and $P_{2}$ be two sites along the BDT at distances along the rift zone from the magma source $x_{1}$ and $x_{2}$, respectively, such that $x_{2}=x_{1}+\Delta x$, with $\Delta x>0$, and the
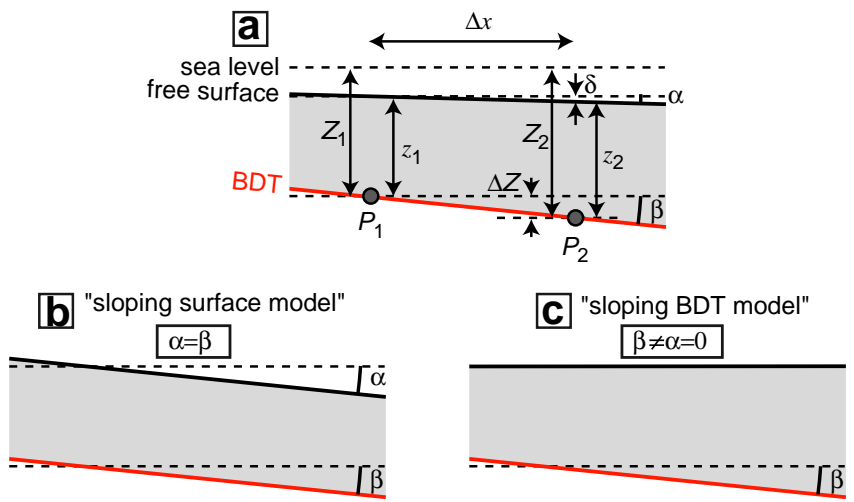

Fig. 5. (a) Geometry of the problem, assuming a migration of magma along the BDT. The free surface and the BDT make an angle $\alpha$ and $\beta$, respectively, with respect to horizontal. $Z$ is the absolute altitude, i.e. the vertical distance with respect to an arbitrary horizontal level, such as sea level. $z$ is the depth below the free surface, i.e. the height of the overlying column of rock. (b) "Sloping surface model". (c) "Sloping BDT model". 
axis $x$ oriented in the direction of magma migration. The change of absolute elevation $\Delta Z$ from $P_{1}$ to $P_{2}$ is therefore:

$\Delta Z=\Delta z+\delta=\Delta z+\Delta x \tan \alpha=\Delta x \tan \beta$

where $\Delta z$ is the change of the height of the overlying rock column from $P_{1}$ to $P_{2}$, and $\delta$ is the change in the absolute elevation of the free surface from $x_{1}$ to $x_{2}$ (positive for a decreasing elevation).

\subsection{Calculation of the horizontal gradient of driving pressure}

\subsection{1. "Sloping surface model"}

In this model, originally proposed by Rubin and Pollard (1987), and later developed by Fialko and Rubin (1998) and Fialko and Rubin (1999), magma is assumed to migrate under the action of its own weight along a level located at a constant vertical distance below a sloping free surface (blue line in Fig. 2). Following the geometry defined above (Fig. 5b), since magma follows a trajectory parallel to the free surface, we have $\beta=\alpha, \Delta z=0$ and $\Delta Z=\Delta x \tan \alpha$ (Eq. 13). Using Eq. (12), the variation of differential stress along the BDT from $P_{1}$ to $P_{2}$ is therefore given by:

$P_{d}\left(P_{2}\right)-P_{d}\left(P_{1}\right)=\Delta P_{d}^{\max }=\rho_{m} g \Delta x \tan \alpha-2 A \rho_{w} g \Delta x \tan \alpha$.

We deduce the horizontal gradient of driving pressure (Eq. 11):

$\left(\frac{\partial P_{d}}{\partial x}\right)_{\text {sloping surface }} \approx \frac{\Delta P_{d}^{\max }}{\Delta x}=\left\{\rho_{m}-2 A \rho_{w}\right\} g \tan \alpha$

Using $A=0.35, \rho_{m}=2700 \mathrm{~kg} / \mathrm{m}^{3}$, and $\rho_{w}=1000 \mathrm{~kg} / \mathrm{m}^{3}$, Eq. (15) may be approximated as:

$$
\left(\frac{\partial P_{d}}{\partial x}\right)_{\text {sloping surface }} \approx 0.74 \rho_{m} g \tan \alpha \approx \frac{3}{4} \rho_{m} g \tan \alpha .
$$

We note that, in spite of the different approaches adopted here, this expression differs only slightly from that proposed by Fialko and Rubin (1998) $\left(\partial P_{d} / \partial x=\rho_{m} g \sin \alpha\right)$. The two expressions yield similar results as long as $\alpha$ is small (say, $<15^{\circ}$ ), which is generally the case in practice, even for the extreme case of the steep slopes of the young volcanic rifts of Hawaii (a maximum of $11^{\circ}$ is found along the flanks of Mauna Loa and Loihi (Fialko and Rubin, 1999).

\subsection{2. "Sloping BDT model"}

In the alternative model proposed in this paper, which we call "sloping BDT model", the increase of the depth of the brittle-ductile transition (BDT) toward segment ends, or, in other words, the increase of the thickness of the elastic-brittle lithosphere, also contributes to the lateral attraction of dykes away from their mid-segment magma source (green line in Fig. 2). In contrast to the "sloping surface model", where the thickness of the elastic-brittle lithosphere was assumed to be constant, the BDT is here sloping at an angle $\beta \neq \alpha$, and occurs at an increasing depth toward the segment end. Therefore, from $P_{1}$ to $P_{2}$, we now have $\Delta Z=\Delta x \tan \beta$, or $\Delta z=\Delta x(\tan \beta-\tan \alpha)$ (Eq. 13). We obtain the following expression for the variation of driving pressure from $P_{1}$ to $P_{2}$ :

$\Delta P_{d}^{\max }=\left\{\left(\Delta \rho+2 A \rho_{r}\right) g \Delta x(\tan \beta-\tan \alpha)\right\}+\rho_{m} g \Delta x \tan \alpha-2 A \rho_{w} g \Delta x \tan \beta$

where we recall that $\Delta \rho=\rho_{m}-\rho_{r}$ is constant. We notice that for $\beta=\alpha$ (i.e. for a dyke travelling at a constant vertical distance below a sloping free surface), Eq. (15) is recovered from Eq. (17). For the sake of separating the effects of a sloping free surface on the one hand, and a sloping BDT on the other, we now assume that $\alpha=0$ and $\beta \neq 0$ (Fig. 5c). This yields:

$\left(\frac{\partial P_{d}}{\partial x}\right)_{\text {sloping BDT }} \approx \frac{\Delta P_{d}^{\max }}{\Delta x}=\left\{\Delta \rho+2 A\left(\rho_{r}-\rho_{w}\right)\right\} g \tan \beta$.

From this expression, it can be deduced that magma buoyancy $\Delta \rho$ (negative for a positively buoyant magma) competes with tectonic stress (second term between braces) in reducing the magnitude of $\partial P_{d} / \partial x$. However, since typically $|\Delta \rho| \ll 2 A\left(\rho_{r}-\rho_{w}\right)$, the effect of tectonic stress is dominant, and magma may be driven laterally for a wide range of values of $\Delta \rho$ (e.g. Rubin, 1995).

Assuming $A=0.35, \rho_{m}=\rho_{r}=2700 \mathrm{~kg} / \mathrm{m}^{3}$ (hence $\Delta \rho=0$ ), and $\rho_{w}=1000 \mathrm{~kg} / \mathrm{m}^{3}$, the above equation reduces to the approximate expression:

$\left(\frac{\partial P_{d}}{\partial x}\right)_{\text {sloping BDT }} \approx 0.44 \rho_{m} g \tan \beta \approx \frac{1}{2} \rho_{m} g \tan \beta$.

This expression is similar to that obtained for the sloping surface model (Eq. 16), suggesting that the two contributions (a sloping free surface and a sloping BDT) have similar magnitudes, provided that $\alpha \approx \beta$. As discussed below, this is usually not the case.

\section{Discussion}

4.1. Quantitative comparison of the efficiency of the two competing models

In order to quantitatively compare the respective efficiency of the two competing models ("sloping surface model" versus "sloping BDT model") in explaining lateral dyke intrusions, we have calculated the expressions of the horizontal gradient of driving pressure along a magmatic rift resulting from an along-axis sloping topographic surface or an along-axis sloping brittle-ductile transition (BDT). These expressions show that comparing the efficiency of the two models is equivalent to comparing the slope of the topographic surface $\alpha$ versus the slope of the BDT $\beta$ (Eqs. 16 and 19, Fig. 2). As demonstrated in the two following examples, usually, $\alpha \ll \beta$ is observed at slow-spreading MORs, which suggests that along-axis variations of the depth of the BDT due to lateral variations of temperature in the lithosphere play a primary role in driving lateral dyke intrusions, whereas the effect of surface topography may be secondary.

Taking the Manda Hararo rift (Ethiopia) as a first example, a shallowing of the BDT above the central magma reservoir is deduced from geodetic analysis of dyke intrusions during the 2005-2010 rifting episode, which provides an indirect insight into the maximum depth of dyke injections (Grandin et al., 2010a,b). As shown in Fig. 1, dykes emplaced above the mid-segment source reservoir are restricted to depths shallower than $\sim 5 \mathrm{~km}$, whereas the bottom depth of dykes reaches $\sim 12 \mathrm{~km}$ at a distance of $10 \mathrm{~km}$ from their mid-segment source toward the north, and $\sim 10 \mathrm{~km}$ at a distance of $10 \mathrm{~km}$ toward the south. A shallow BDT at the segment centre is also supported by observations of transient deformation occurring in the $4-10 \mathrm{~km}$ depth range at segment centre between discrete periods of dyke intrusions (Grandin et al., 2010a). Unfortunately, hypocentral depths in the Manda Hararo rift are poorly constrained due to the inadequate station coverage and the low magnitude of events, which precludes a direct estimate of the absolute value of the depth to the BDT, as well as of the along-rift variations in the thickness of the brittle layer suggested by space geodetic observations (e.g. Grandin et al., 2011). Nevertheless, available seismological data shows that both the number and the magnitude of earthquakes detected in 2005-2010 exhibit a clear minimum near the central magma reservoir, and an increase toward both segments ends (Belachew et al., 2011; Ebinger et al., 2008; Grandin et al., 2011; Keir et al., 2006). This is compatible with 
a Afar, Iceland

segment centre

segment end
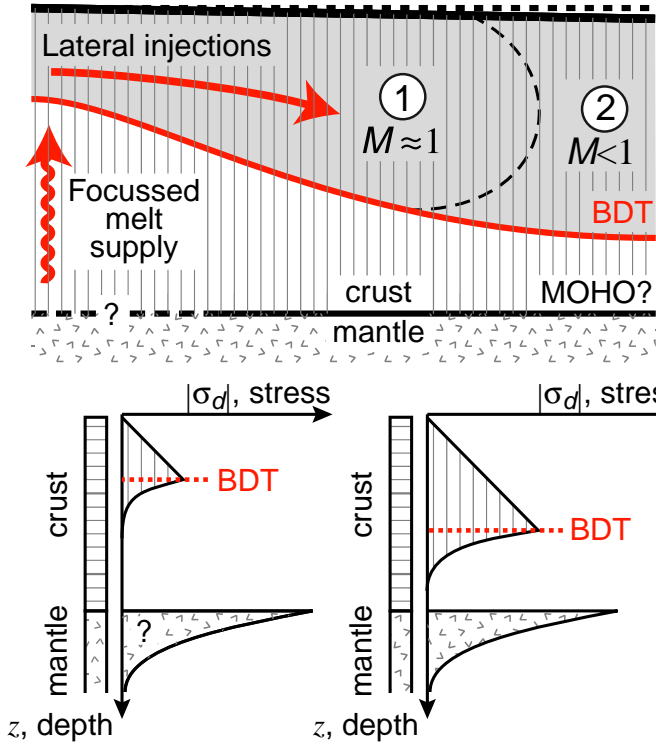

segment centre

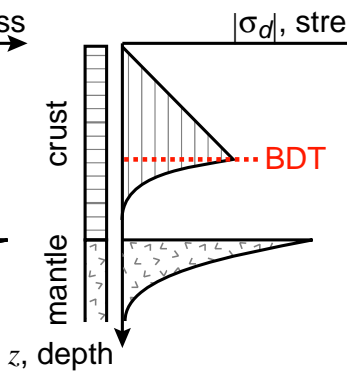

segment end b Mid-Atlantic Ridge
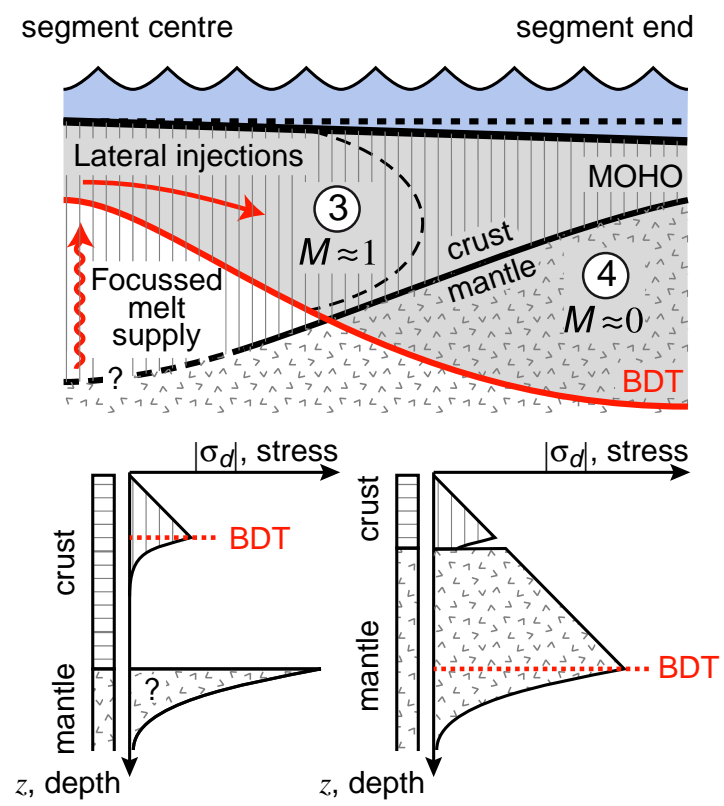

segment centre

segment end

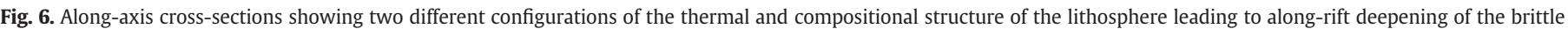

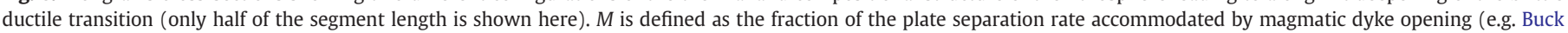

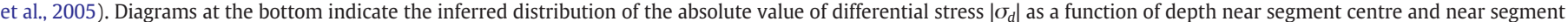

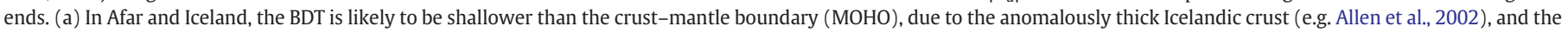

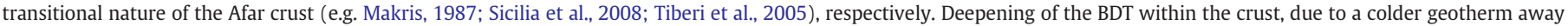

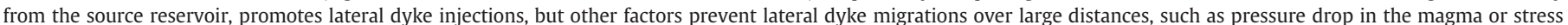

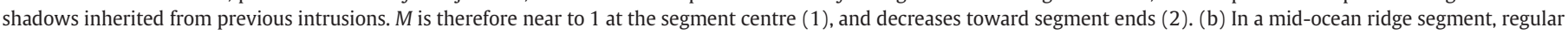

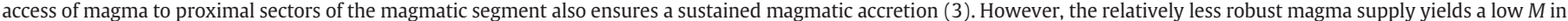

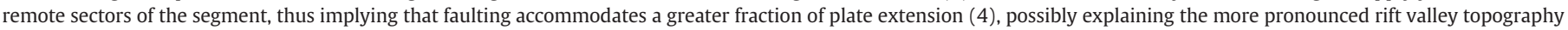
in comparison to sub-aerial rifts.

a mid-segment weakness of the lithosphere, presumably due to focussed melt supply at the rift centre, a view supported by other geophysical evidence from the neighbouring Asal rift (Djibouti) (e.g. Doubre et al., 2007a,b) (Fig. 6a). Assuming the dykes bottom lies near the BDT (case of a buoyant magma, i.e. $\rho_{m}<\rho_{r}$ in Fig. 4a), geodetic observations of the 2005-2010 dyke intrusions yield an estimated $\beta=70 \%\left(35^{\circ}\right)$ toward the north, and $\beta=50 \%\left(27^{\circ}\right)$ toward the south. Alternatively, if one assumes that the mid-depth of dyke intrusions follows the BDT (no density contrast between magma and host rock, i.e. $\rho_{m}=\rho_{r}$ in Fig. 4 a), these estimates of $\beta$ should be divided by a factor 2 , leading to $\beta=35 \%\left(19^{\circ}\right)$, and $\beta=25 \%\left(14^{\circ}\right)$, respectively. In comparison, much smaller values of the along-axis topographic slope $\alpha$ are typically found in sub-aerial rift segments of Iceland and Afar, with slopes of the order of $\alpha=1.0-1.5 \%\left(0.6-0.9^{\circ}\right)$ (Buck et al., 2006; Grandin et al., 2009) (Fig. 1a).

A second example is the well-studied $\sim 50 \mathrm{~km}$-long magmatic segment located at $29^{\circ} \mathrm{N}$ on the slow-spreading MAR. Geophysical and geomorphologic observations show that the features of this magmatic segment are typical of those found in most second-order magmatic segments of the MAR (Sempéré et al., 1993). The "bull's eye" gravity anomaly at the centre of the segment is compatible with a decrease of the oceanic crustal thickness from $7.5 \mathrm{~km}$ at segment mid-point, to $4 \mathrm{~km}$ at segment end (Lin et al., 1990). At slow-spreading MORs, a thick crust at the segment centre is generally thought to correspond to a thin upper elastic-brittle layer, because the strength of the lithosphere is dramatically decreased by the presence of a weak lowercrust which decouples the upper crust from the stronger underlying mantle (Fig. 6b). In contrast, segment ends are characterised by a thinner crust, leading to a full coupling of the crust and the mantle, so that the strength of the lithosphere is substantially greater there (e.g. Cannat, 1996; Shaw, 1992; Thibaud et al., 1999). Therefore, focusing of melt induces a thermal and compositional weakening of the lithosphere near segment centres, whereas cold segment ends can sustain more differential stress before yielding. Rheological models predict that the strength of the lithosphere depends, to the first order, on the local geotherm. The $600-700{ }^{\circ} \mathrm{C}$ isotherm is commonly considered as a proxy of the BDT, because at higher temperatures plastic flow in the gabbros is expected (e.g. Tapponnier and Francheteau, 1978). Tridimensional thermo-mechanical modelling of lithospheric deformation provides an estimate of the thermal profile as a function of depth and distance along the rift axis of this segment of the slow-spreading MAR (Shaw and Lin, 1996). Assuming "dry diabase" lithology for the crust, and "dry dunite" for the underlying lithospheric mantle, the depth of the BDT deduced from these thermal profiles increases from 6-7 km at segment centre, to $9 \mathrm{~km}$ at a distance of $7 \mathrm{~km}$ along the axis, for a point located at $1 \mathrm{~km}$ offaxis (i.e. for a $80 \mathrm{kyr}$ old lithosphere and a half-spreading rate of $1.2 \mathrm{~cm} / \mathrm{yr}$ ) (Hirth et al., 1998). We deduce that the slope of the BDT is in the range $\beta=28-42 \%\left(16-23^{\circ}\right)$ for this segment of the MAR. This is in good agreement with values in the range $\beta=27-100 \%$ $\left(15-45^{\circ}\right)$ proposed for the along-axis slope of the $700{ }^{\circ} \mathrm{C}$ isotherm in the MAR, from thermal modelling of the axial oceanic lithosphere (Fontaine et al., 2008). In comparison, an upper bound for the along-axis topographic slope in the slow-spreading MAR is only $\alpha=4 \%\left(2.3^{\circ}\right)$ (Sempéré et al., 1993).

From these two examples, we conclude that the along-axis slope of the BDT $\beta$ may be significantly steeper than the along-axis slope of surface topography $\alpha$. Using typical values of $\alpha$ and $\beta$, and applying the formulas developed in the previous section, values of the corresponding horizontal gradient of driving pressure $\partial P_{d} / \partial x$ are readily 
calculated. For a topographic slope of $\alpha=1-4 \%\left(0.6-2.3^{\circ}\right)$, we obtain $\left(\partial P_{d} / \partial x\right)_{\text {sloping surface }}=0.20-0.78 \mathrm{MPa} / \mathrm{km} \quad($ Eq. 15), whereas for an along-axis BDT slope in the range $\beta=10-40 \%\left(5.7-22^{\circ}\right)$, we find $\left(\partial P_{d} / \partial x\right)_{\text {sloping BDT }}=1.1-4.6 \mathrm{MPa} / \mathrm{km}$ (Eq. 18), using $A=0.35, g=$ $10 \mathrm{~m} . \mathrm{s}^{-2}, \rho_{m}=2650 \mathrm{~kg} / \mathrm{m}^{3}, \rho_{r}=2700 \mathrm{~kg} / \mathrm{m}^{3}$ and $\rho_{w}=1000 \mathrm{~kg} / \mathrm{m}^{3}$ in both cases. We conclude that the thickening of the elastic-brittle lithosphere away from the magma source due to melt focusing at rift centre is more efficient (by a factor 5) than commonly observed along-axis topographic slopes to drive dykes laterally in a slowspreading MOR setting.

\subsection{Surface topography: cause or consequence of lateral dyke intrusions?}

Although we show that variations of elastic-brittle thickness are capable of efficiently driving lateral dyke injections, our calculations do not preclude that surface topography does play a role in increasing the horizontal gradient of driving pressure in volcanic rift zones, as suggested by the observation of a correlation between dyke opening and surface elevation in the Krafla rift (Buck et al., 2006). In fact, in the case of a prominent volcanic edifice, such as in Hawaii (e.g. Mauna Loa, Kilauea), surface topography is likely to be an important factor driving the lateral migration of magma pockets along the slope of the rift zone (Fialko and Rubin, 1999; Pinel and Jaupart, 2004). In addition, other mechanisms not taken into account in this analysis may also influence the spatial arrangement of rift zones, such as flank instability associated with detachment faulting below the edifice (Amelung et al., 2007; Rubin, 1990; Walter et al., 2005). Therefore, depending on the tectonic setting, on edifice shape and height, and on magma composition, temperature and supply rate, these competing contributions may lead to lateral dyke intrusions unrelated to any change in the depth to the BDT.

Nevertheless, relevance of the "sloping BDT model" in a slowspreading MOR setting is supported by the recent observations of dyke intrusions in Afar, which show that surface elevation and dyke opening are poorly correlated, likely indicating that dyke emplacement cannot be controlled, in this case, by topography (Grandin et al., 2010b) (Fig. 1c). In fact, the morphology of the axial valley of MOR magmatic segments is the result of a competition between the creation of topography by activity of normal faults, and the potential of occasional periods of enhanced volcanic activity to "reset" the topography (e.g. Behn et al., 2006; Parsons and Thompson, 1991; Rubin, 1992). Because dyke intrusions both trigger fault slip and often lead to axial eruptions, long-term variations of melt supply to the rift segment can produce a succession of periods of topography creation (tectonic phase) and destruction (volcanic phase). The Asal rift provides a compelling example of the competition between faulting and volcanism in controlling the axial topography of a magmatic rift. There, restoration of topography has shown that today's rift topography is the result of the dismantlement of a prominent central volcano (Fieale), due to reduced extrusive volcanic activity since $\sim 100 \mathrm{ka}$, and consequently enhanced activity on normal faults, fissures and dykes (de Chabalier and Avouac, 1994; Manighetti et al., 1998). Similarly, in the Manda Hararo rift, the presence of a partially dismantled mid-segment transverse volcanic range, including the Ado'Ale volcano which culminates at $\sim 1400 \mathrm{~m}$ (Grandin et al., 2009; Rowland et al., 2007), suggests that the remnants of a preexisting landscape may also represent a significant component of today's axial topography. Finally, the importance of intrusive activity at early stages of lithospheric rupture, such as in the East African rift (Calais et al., 2008; Keir et al., 2006, 2011), also suggests that lateral dyke intrusions can predate the establishment of an equilibrium axial topography similar to that observed in "steady-state" segments of the slow-spreading MOR. Therefore, in the young volcanic rifts of the Afar depression (<1-2 Myr (Barberi et al., 1972; Manighetti et al., 2001)), the topography that preceded the onset of oceanic-like accretion at the rift axis may still substantially contribute to today's along-axis relief, possibly explaining the absence of any correlation (either positive or negative) between dyke opening and surface elevation in the recent Manda Hararo rifting episode. This contrasts with the Northern Volcanic Zone of Iceland, where oceanic-like accretion has been occurring for a longer time (at least $8 \mathrm{Myr}$ ), at a faster velocity ( $2 \mathrm{~cm} / \mathrm{yr}$ ), and with a comparatively higher magma supply rate (e.g. Garcia et al., 2003; Rubin, 1990), probably explaining why, in the Krafla rift, axial rift topography appears to be already in equilibrium with along-axis variations in magma supply (Behn et al., 2006). An open question is whether the central volcanoes (Fieale, Ado'Ale, Krafla) associated with a prominent topography may be interpreted as precursors of the localisation of the rift zone (Lahitte et al., 2003). This could perhaps occur by a process of thermal punching of the lithosphere, that would promote magma focusing and the development of a dyke swarm around this newly-created soft point (e.g. Doubre and Geoffroy, 2003; Geoffroy, 2001).

In contrast, the topography of second-order segments of the MidAtlantic Ridge (MAR) is generally considered to reflect nearly steadystate processes of accretion. A widespread observation in the MAR is the greater depth and breadth of the axial graben near segment ends compared to segment centre (Escartín et al., 1997; Shaw, 1992; Thibaud et al., 1999). This hour-glass shaped topography of the rift valley is likely the result of a higher ratio of tectonic to magmatic extension toward segment ends where faulting processes are enhanced by the greater depth to the BDT (Buck et al., 2005; Harper, 1985) (Fig. 6b). Similar observations in the Asal rift of Djibouti (Doubre et al., 2007a; Pinzuti et al., 2010) may suggest that the same first-order along-strike structure of the lithosphere may be already present at the incipient stage of lithospheric rupture in which the Manda Hararo rift appears to be standing today. Yet, a striking issue is the marked difference in the heave of grabenbounding normal faults observed in sub-aerial sectors of the global MOR system in Afar or Iceland (a few hundred metres to the most) compared to the MAR (up to $2000 \mathrm{~m}$ ). The fraction of the plate separation rate accommodated by magmatic dyke opening ( $M$ in Fig. 6) has been shown to play a significant role in controlling the acrossaxis topography of MORs (Buck et al., 2005), as is well illustrated by the end-member case of oceanic core complexes, associated with low-angle detachment faulting and mantle exhumation, occurring near segment ends in some ultraslow magma-poor MOR segments (Cannat et al., 2006; Lagabrielle et al., 1998). The difference between the MAR and Afar/Iceland can be explained by the melt-richer environment in the volcanic rift zones in Afar and Iceland induced by hotspot activity. However, the impact of along-axis variations of $M$ on the topography of a single rift segment has not been fully explored. Resolving this issue would require to account for the $4 \mathrm{D}$ thermo-mechanical interplay between magma migration, fault growth, mantle flow and hydrothermal processes.

\subsection{Limitations and possibilities for improvement}

In our analysis, we have made the assumption that along-axis variations of the elastic-brittle thickness $H$ arising from the thermal state of the young oceanic lithosphere in the presence of a focusing of melts at segment centre are capable of creating conditions that substantially encourage lateral dyke escape away from the mid-segment magma-rich region. In this section, we assess the importance of a number of factors that have been excluded from the analysis.

First, we do not take into account the decrease of magma pressure during the intrusion, as a result of melt extraction from a finite-sized source reservoir (Dvorak and Okamura, 1987; Einarsson and Brandsdóttir, 1980; Ida, 1999; Owen et al., 2000; Rivalta, 2010), or due to viscous pressure losses during magma transport to the dyke tip region (e.g. Lister and Kerr, 1991; Spence and Turcotte, 1985; Wada, 1994). Similarly, heat exchange with the host rock tends to promote magma solidification and to limit dyke propagation (Fialko 
and Rubin, 1998; Spence and Turcotte, 1985). Finally, intrusion of a dyke is expected to contract the surrounding rocks off to the sides of the magma body, which results in a consumption of the elastic strain energy driving the dyke intrusion. In the absence of a high magma pressure, the volume of magma that can be intruded in dykes is ultimately limited by the deficit of opening inherited from inter-dyking plate divergence and a potentially complex sequence of previous intrusions (Grandin et al., 2010b). All these factors (pressure drop in the magma, magma freezing at the dyke tip, decrease of $\left|\sigma_{d}\right|$ as a result of previous intrusions) tend to decrease the driving pressure during the dyke intrusion, and eventually control the conditions for dyke arrest in a sense that limits the volume and distance of propagation of dykes. Including these mechanisms in the analysis could help understanding the effect of successive magma intrusions on the spatial and temporal patterns of dyke intrusions during a full rifting episode (e.g. see the model of Buck et al., 2005). This would however require the implementation of a substantially more complex model of dyke intrusion than the semi-quantitative strategy adopted here, which accordingly maximises the effect of geometrical parameters (slope of the BDT, slope of the surface) in driving lateral dyke injections.

Another critical assumption is that the sign and magnitude of the horizontal gradient of driving pressure $P_{d}$ is used as a means of quantifying the propensity for lateral dyke injections, by stating that lateral dyke injections are promoted when $\partial P_{d} / \partial x>0$. In our analysis, the condition $\partial P_{d} / \partial x>0$ is satisfied because the lithosphere is assumed to be in a state of incipient faulting at all depths ("faulting stress case"), so that the magnitude of relative tension $\left|\sigma_{d}\right|$ increases toward thick, cold segment ends. This scenario should be appropriate at the initiation of a major rifting episode because, at that time, relative tension is expected to have reached a significant fraction of the maximum imposed by the brittle strength envelope, as suggested by the observation that the initial dykes intruded in a rifting episode are generally non-eruptive, despite their large volume (e.g. December 1975 dyke in Krafla, September 2005 dyke in Manda Hararo). This scenario is also compatible with the view that dykes in Afar and Iceland, and probably also in slow-spreading MORs, are intruded at low magma pressure and high extensional stress (Grandin et al., 2010b; Rubin, 1990). Similar conclusions would be reached for any scenario where $\partial\left|\sigma_{d}\right| / \partial x>0$, provided that magma pressure decrease during the injection is discounted.

Alternatively, we could have assumed a uniform $\left|\sigma_{d}\right|$ above the BDT ("uniform stress case") (e.g. Qin and Buck, 2008). This second scenario could be appropriate for a lithosphere at an intermediate stage of loading, i.e. with relative tension lower than the limit imposed by yield criteria for normal faulting. In this case the horizontal gradient of driving pressure $\partial P_{d} / \partial x$ would be rigorously equal to zero, which would neither promote nor prevent lateral dyke intrusions. This appears to be counter-intuitive, because a greater thickness of the lithosphere toward segment ends means more room is available for dyke intrusions. This suggests that $\partial P_{d} / \partial x$ is a restrictive parameter to quantify the lateral attraction of dykes, and that our approach may be conservative. An alternative means of quantifying the balance between the actions of tectonic stress and magma pressure "sensed" by dyke intrusions is to introduce the "force available for driving dyke injection", defined as the integral of the driving pressure over the thickness $H$ of the lithosphere (Buck, 2006):

$F_{d}=\int_{0}^{H} P_{d}(z) d z$

Using this new expression and Eq. (5), and assuming a constant magma overpressure $p_{0}$ and no magma buoyancy (i.e. $P_{d}(z) \equiv-\sigma_{d}$ ), we find that, in the uniform stress case, $F_{d}$ is proportional to $H$. This would promote lateral dyke intrusions toward regions of greater elastic-brittle thickness in the uniform stress case, though less efficiently than in the tectonic stress case (where $F_{d}$ would be proportional to $H^{2}$ ). More precisely, in the uniform stress case, the efficiency of the sloping BDT model would be decreased as the ratio between the average (uniform) level of relative tension in the elastic-brittle lithosphere and the maximum relative tension derived from yield criteria, so that lateral dyke intrusions would be less likely to occur when tectonic stress becomes low. This scenario may apply to late stages of a rifting episode, when tectonic stress has been "consumed" by a succession of previous dyke injections. This could explain the observed shift from the intrusion of voluminous, non-eruptive dykes travelling over long distances at the beginning of a rifting episode (e.g. December 1975 dyke in Krafla, September 2005 dyke in Manda Hararo), followed by an increasing tendency for intrusion of smaller dykes travelling over shorter distances, associated with more frequent lava extrusion in the late stages of the rifting episode (e.g. the eruptive dykes in 1980-1984 in Krafla, the two last observed dykes of June 2009 and May 2010 in Manda Hararo) (Björnsson, 1985; Buck, 2006; Ferguson et al., 2010; Grandin et al., 2010b).

A third scenario could be that of a uniform force $F_{d}$ ("uniform force case"). This scenario gives primacy to stress focusing in the thin elastic layer overlying a weak segment centre (e.g. see Gac and Geoffroy, 2009), and implies that the magnitude of extensional stress has to decrease substantially toward the thicker segment ends (i.e. relative tension evolves as $1 / H$, so that $\left.\partial\left|\sigma_{d}\right| / \partial x<0\right)$. Because magma pressure is not likely to increase during horizontal propagation, this scenario would lead to $\partial P_{d} / \partial x<0$. This represents a repulsion of magma in the $x$ direction, so this situation is less conducive to lateral dyke propagation. Nevertheless, provided that magma is efficiently trapped at depth and that dyke inflation is sustained by sufficient magma pressure, lateral dyke migration may still occur. For instance, as long as magma pressure $p_{m}$ exceeds the normal stress $\sigma_{3}$ but is less than the burden stress $\sigma_{1}$, inflation of a dyke at the BDT would lead to its coeval horizontal expansion along the BDT, as shown by Lister and Kerr (1991). However, dykes intruded in such a situation would narrow downrift, and their maximum thickness would be observed at the magma source where driving pressure is maximum. This appears to be incompatible with observations of dyke injections in the early stages of rifting episodes at Manda Hararo and Krafla, because maximum dyke width occurred $10-30 \mathrm{~km}$ away from the source reservoir for most of these intrusions. Therefore, similarly to the "uniform stress case", the "uniform force case" could only apply to the late stage of a rifting episode when observations show that most dykes give rise to an eruption above the magma chamber. However, this would imply a reversal of the sign of $\partial P_{d} / \partial x$ between the inception of a rifting episode (positive, "faulting stress case") and its end (negative, "uniform force case"). Although $P_{d}$ may be efficiently decreased toward segment ends as a result of multiple dyke intrusions, this scenario requires a second mechanism to coevally increase the magnitude of $P_{d}$ locally at segment centre. This shift from a lateral attraction to a lateral repulsion should occur over the short duration of a rifting episode (a few years), which excludes "passive" tectonic stretching. An hypothetic candidate mechanism could be the decrease of rift-normal compressive stress $\sigma_{n}$ due to stress transfer from the intrusion of neighbouring dykes surrounding the rift centre (Grandin et al., 2010b; Hamling et al., 2010) or the transient inflation of a magma body located below the BDT at the rift centre (Amelung et al., 2007; de Zeeuw-van Dalfsen et al., 2004; Grandin et al., 2010a). Unfortunately, too little information is available to support the significance of such a mechanism.

In a fourth scenario, differential stress could be highly heterogeneous along the plate boundary as a result of a complex history of past intrusions and eruptions, so that systematic variations of elasticbrittle thickness would become irrelevant to explain in detail lateral dyke injections. In that scenario, dykes would tend to emplace preferentially in sectors of the rift where relative tension is maximum. Conversely, local minimas of the magnitude of extensional stress would likely act as barriers to dyke propagation. Consequently, 
magma access to remote sectors of the rift zone could be extremely difficult due to the presence of multiple barriers along the magma pathway, and magma would likely accumulate near the central magma source. Therefore, relative tension could not develop to a high level in the vicinity of the magma source, in contrast to magma-starved sectors of the rift near segment ends. Because the magnitude of extensional stress is ultimately limited by the yield strength of the lithosphere, after many dyke intrusions, the situation would likely stabilise to one of the above scenarios. However, a more complex approach than that chosen in this paper would be required to ascertain this assertion.

\subsection{Kinematic approach}

We have showed that variations of the thickness of the axial elastic-brittle lithosphere at MOR segments may give rise to stress conditions that promote lateral migration of magma within the lithosphere more efficiently than an along-axis topographic slope. This has been demonstrated semi-analytically, and quantified for ranges of plausible values of the along-axis slope of the BDT and topographic surface inferred from geophysical observations. Accordingly, our line of argumentation stands on numerous hypotheses on the distribution of stress within the lithosphere, and we made a series of simplifications of the complex physics of dyke intrusion. Nevertheless, our key argument is that the along-axis increase of the elastic thickness away from segment centre, presumably caused by thermal weakening of the lithosphere above a mid-segment magma supply, induces a lateral appeal of dykes toward segment ends, i.e. away from segment centre. Setting aside other assumptions, it is possible to use a kinematic reasoning to show qualitatively that a thicker elastic-brittle layer at segment ends is likely to be a critical parameter to explain lateral dyke injections.

Let us assume that magma injection in dykes is the only process of accretion in the elastic-brittle layer of the lithosphere (i.e. the fraction of the plate separation rate accommodated by magmatic dyke opening $M$ is uniformly equal to 1 ). Starting from a lithostatic stress state, after moderate stretching of the lithosphere, stress amplification near the segment centre, where the lithosphere is thin, implies that the lithosphere can reach a state of incipient faulting much faster at the segment centre than near the thick segment ends. Therefore, the higher level of extensional stress near the magma source must be relieved by more frequent intrusions, whereas buildup of relative tension can proceed for a longer time near segment ends. However, dykes emplaced near the segment centre are expected to involve small volumes of magma because of scaling relationships: if the dykes are restricted to emplace in a thin layer above the magma reservoir, their length and thickness will remain small (Fig. 7a). Conversely, after a long period of loading, once segment ends have reached the limit imposed by yield criteria for faulting, any dyke penetrating in a distal sector of the rift zone has to accommodate a much more important deficit of strain, both because of the greater thickness of the column of stretched rocks, but also because of the longer time interval since the previous dyke.

To better quantify these effects, let us assume that accretion proceeds solely by intrusion of dykes whose heights equal the thickness of the elastic layer $H$, and whose lengths are noted $l$. Given a full spreading rate $u$, the long-term intrusion rate $\dot{V}$ required to compensate plate divergence at any site with elastic thickness $H$ can be expressed as:

$\dot{V}=l H u$.

This intrusion rate averaged over a long time period can be related to the volume of individual dykes $V$ via their injection frequency $I_{f}$ :

$\dot{V}=V I_{f}$.
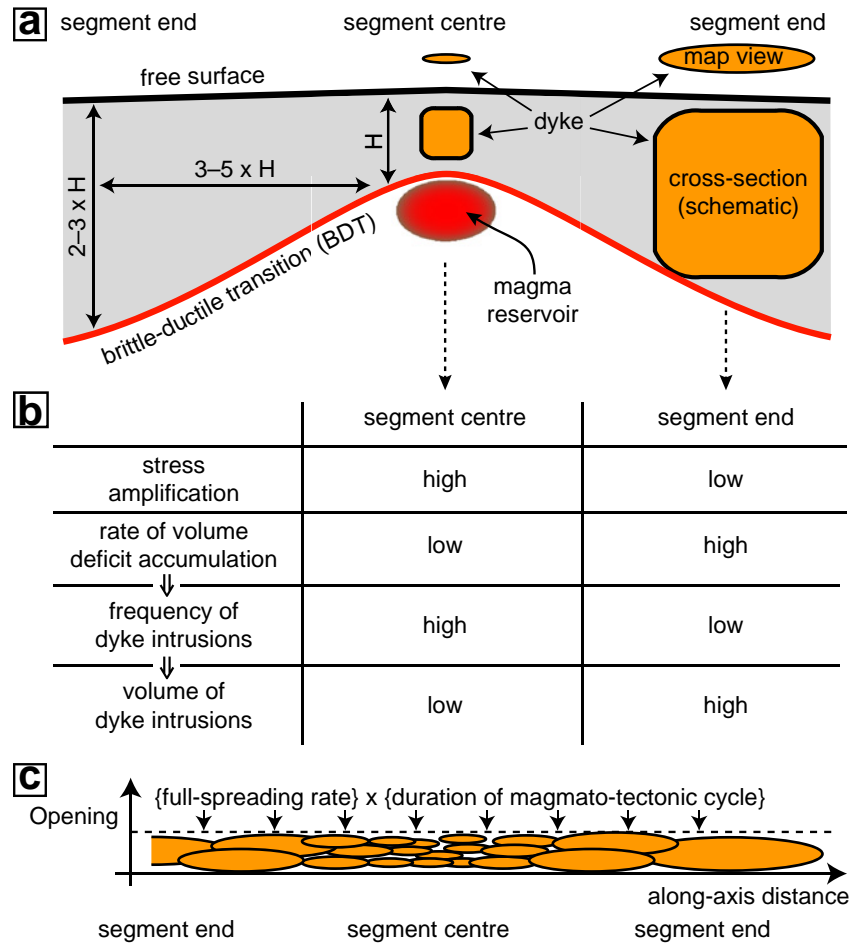

Fig. 7. (a) Dykes emplaced near segment centre are thinner, shorter and smaller than those intruded at segment ends because of scaling laws and the limit imposed by the local thickness of the elastic-brittle lithosphere. (b) For a constant spreading rate, stress builds up at a faster rate near segment centre because of stress amplification, but less magma volume is required to accommodate spreading on the long run. Hence, frequent, small volume dykes are required. Conversely, dyke intrusions are less frequent near segment ends, but their volume is significantly larger. (c) Frequent, thin dykes near segment centre, and infrequent, thick dykes near segment ends can maintain a constant rate of opening and a steady-state accretion.

The volume of an individual dyke intrusion is the product of its length $l$, height $H$ and thickness $d$, if we assume that its shape can be approximately described by these three geometric dimensions:

$V=l H d$

Scaling relationships between $l, H$ and $d$, which are explained by the theory of Linear Elastic Fracture Mechanics (LEFM), require that $l, H$ and $d$ are approximately proportional to each other (Grandin et al., 2010b; Pollard and Segall, 1987), so that the above equations can be rewritten as:

$\dot{V}=k H^{2} u=V I_{f}$

$V=k k^{\prime} H^{3}$

where $k$ and $k^{\prime}$ are coefficients of proportionality between $l$ and $H$, and $d$ and $H$, respectively. For simplicity, we assume that dyke aspect ratio $k=l: H$ is of the order of 1 (Grandin et al., 2010b). $k^{\prime}$ is in the range $10^{-2}$ to $10^{-4}$ (Rubin, 1995). Thus, the two above equations can be combined to provide an expression of the injection frequency:

$I_{f}=\frac{1}{k^{\prime}} \frac{u}{H}$

Using these expressions, and assuming an increase of the elasticbrittle thickness $H$ by a factor 2 between segment centre and segment ends, we find (1) that dyke intrusions are more frequent by a factor 2 near segment centre than near segment ends, and (2) that individual dykes are more voluminous by a factor 8 near segment ends compared 
to segment centre (Fig. 7c). This is compatible with field observations in eroded dyke swarm, which show (1) that dykes are fewer in number at the distal ends of rift zones, as discussed by Rubin (1995) (reporting observations from Gudmundsson, 1990; Speight et al., 1982; Walker, 1987), and (2) that dykes are also greater in thickness there (e.g. Paquet et al., 2007).

Grandin et al. (2010b) have reported observations of the 2005-2010 sequence of 14 dyke intrusions in the Manda Hararo rift that allow us to further constrain the along-strike variability of the frequency of dyke intrusions as a function of elastic thickness. Note that Grandin et al. (2010b) provide values of $k^{\prime}$ for each dyke intrusion, which they refer to as the average normal strain change associated with a dyke intrusion. Dykes injected near the magma source, where $H=5 \mathrm{~km}$, typically have strain drops of $k^{\prime}=1.0 \times 10^{-4}$, which yields a recurrence time of $25 \mathrm{yr}$ (using $u=20 \mathrm{~mm} / \mathrm{yr}$ ). In contrast, the thickest dykes injected $10-20 \mathrm{~km}$ to the north of the midsegment magma source, where $H=12 \mathrm{~km}$, have larger strain drops of $k^{\prime}=5 \times 10^{-4}$, so that the recurrence time associated with these voluminous dykes is $450 \mathrm{yr}$. Shorter time intervals between rifting episodes (100-150 years) are inferred from historical observations in the Northern Volcanic Zone of Iceland, despite a similar spreading rate (Björnsson et al., 1977). This would fit with a thinner axial lithosphere in the steady-state magma-rich rifts of NE Iceland compared to young rifts of the Afar depression, where plate breakup is still in an incipient stage (Hayward and Ebinger, 1996).

This simple kinematic model, supported by observations of past and recent dyke intrusions, suggests that the region located near the mid-segment source reservoir could host frequent dykes of small volumes, whereas dyke intrusions at segment ends are less frequent, but more voluminous. Yet, more frequent, smaller volume dyke intrusions near segment centre, although predicted by this model, have not been observed so far. Rather, dyke intrusions in Afar and Iceland appear to be clustered in time during rifting episodes (e.g. Ebinger et al., 2010). Such a clustering probably involves elastic interactions between dyke intrusions (Grandin et al., 2010b; Hamling et al., 2010) and an unresolved mechanism of melt supply to the finite-size feeder reservoir during the short interval (3-12 months) between discrete dyke intrusions. Nevertheless, dyke intrusions near the mid-segment magma source were indeed more numerous than toward segment ends during the rifting episodes of Krafla and Manda Hararo (Björnsson, 1985; Grandin et al., 2010b; Hamling et al., 2009). Therefore, the intrusion frequency $I_{f}$ could be better defined as the cumulative number of intrusions at a given site along the rift axis throughout the duration of a complete rifting episode.

This model does not preclude that small dyke intrusions near the segment centre may occur in the time intervals separating major rifting episodes, but evidence for such isolated events is difficult to find. This could be due to an insufficient time of observation, because small dyke intrusions may be nearly aseismic and do not necessarily generate an eruption, so that past dyke intrusions may well have remained unnoticed prior to the development of modern remote sensing techniques. For instance, detection of a major dyke intrusion coeval with the 1978 "volcanic-seismic" crisis in the Asal rift (Afar, Djibouti) would have been impossible without the prior installation of a dedicated geodetic network (Ruegg et al., 1979). The growing number of examples of dyke intrusions imaged recently by spaceborne geodesy in remote areas of the broad East African Rift-Red Sea region could also support this view (e.g. Calais et al., 2008; Keir et al., 2011; Pallister et al., 2010; Wright et al., 2006). In addition, other processes not involving magma intrusion are also capable of accommodating plate divergence in the mid-segment region during inter-rifting periods, including episodic fault creep above the central magma reservoir (Doubre and Peltzer, 2007) or visco-elastic deformation of a weak layer overlying the deeper deforming rift body (Pedersen et al., 2009). These mechanisms, although more difficult to detect, may efficiently limit the level of relative tension at rift centre above the BDT between major episodes of dyke intrusions.

\section{Conclusion}

Lateral dyke intrusions travelling along the axis of magmatic rifts, such as in the slow-spreading sectors of the mid-ocean ridge system during rifting episodes, are an important process of accretion in the uppermost part of the elastic-brittle oceanic lithosphere. It had previously been proposed that lateral dyke intrusions, which result from the existence of a horizontal gradient of driving pressure along the rift, are mainly driven by the along-rift topographic downward slope that is commonly observed in magmatic rifts toward segment ends. In this paper, we alternatively propose that the increase of elastic-brittle thickness toward segment ends along the rift axis is a more plausible explanation of the phenomenon of lateral dyke intrusions. The underlying reason is that a greater amount of potential elastic strain energy can be stored near segment ends, because the brittle-ductile transition (BDT) can be significantly deeper there than near the mid-segment magma source. This increase of the elastic-brittle thickness toward segment ends is due to the colder geotherm that prevails in distal sectors of the rift, in contrast to the mid-segment region where the lithosphere is thermally weakened by focused melt ascent from the asthenosphere. Geophysical observations in the mid-Atlantic ridge, Afar and Iceland support the hypothesis of a thin, presumably weak segment centre, and comparatively thicker, stronger segment ends. Using a semi-analytical formulation, we calculate that dykes are attracted laterally in proportion of the along-axis slope of the BDT. Similarly, in the topography-driven dyke propagation hypothesis, the lateral gradient of driving stress is proportional to the along-axis slope of the free-surface. For typical values of the slope of surface elevation and BDT in slow-spreading mid-ocean ridge contexts, we show that thickening of the elastic-brittle lithosphere is up to five times more efficient than a sloping of surface topography in promoting lateral dyke injections. In addition, we argue that rift topography may be the consequence of lateral dyke injections, rather than their cause. Indeed, along-axis variations of elastic-brittle thickness, which are ultimately controlled by the efficiency of melt distribution along the ridge, may be capable of leading to the development of the observed typical rift morphology (along-axis increase of the breadth and height of riftbounding normal faults) because fault slip is enhanced near "strong", magma-starved segment ends, and faults are consequently more deeply rooted there. Conversely, apparent fault heave is decreased near the magma-rich segment centre due to more efficient magma supply and more frequent axial eruptions. Therefore, the "sloping BDT model" provides a general explanation for the phenomenon of lateral dyke intrusions in the specific magmato-tectonic environment of slowspreading mid-ocean ridges.

\section{Acknowledgments}

We thank five anonymous reviewers and Editor Yanick Ricard for their constructive remarks on the manuscript. We pay homage to Kassim Mohamed Kassim, Director of the Arta Geophysical Observatory of Djibouti, who died prematurely. He worked on the seismic activity in Afar and helped to access the data. This work was part of the DoRA project of the French ANR Agency.

\section{References}

Abdallah, A., Courtillot, V., Kasser, M., Le Dain, A.-Y., Lépine, J.-C., Robineau, B., Ruegg, J.-C., Tapponnier, P., Tarantola, A., 1979. Relevance of Afar seismicity and volcanism to the mechanics of accreting plate boundaries. Nature 282, 17-23 Nov..

Allen, R.M., Nolet, G., Morgan, W.J., Vogfjörd, K., Nettles, M., Ekström, G., Bergsson, B.H., Erlendsson, P., Foulger, G.R., Jakobsdóttir, S., Julian, B.R., Pritchard, M., Ragnarsson, S., Stefánsson, R., 2002. Plume-driven plumbing and crustal formation in Iceland. J. Geophys. Res. 107, 2163 Aug. 
Amelung, F., Yun, S.-H., Walter, T.R., Segall, P., Kim, S.-W., 2007. Stress control of deep rift intrusion at Mauna Loa Volcano, Hawaii. Science 316, 1026-1030 May.

Anderson, E.M., 1938. The dynamics of sheet intrusion. Proc. R. Soc. Edinb. 58, 242-251.

Ayele, A., Keir, D., Ebinger, C.J., Wright, T.J., Stuart, G., Buck, R., Jacques, E., Ogubazgh, G. Sholan, J., 2009. The September 2005 mega-dike emplacement in the MandaHarraro nascent oceanic rift (Afar depression). Geophys. Res. Lett. 36.

Barberi, F., Tazieff, H., Varet, J., 1972. Volcanism in the Afar depression: its tectonic and magmatic significance. Tectonophysics 15, 59-64 Oct.

Behn, M.D., Buck, W.R., Sacks, I.S., 2006. Topographic controls on dike injection in volcanic rift zones. Earth Planet. Sci. Lett. 246, 188-196 Jun.

Belachew, M., Ebinger, C.J., Cote, D.M., Keir, D., Rowland, J.V., Hammond, J.O.S., Ayele, A., 2011. Comparison of dike intrusions in an incipient seafloor-spreading segment in Afar, Ethiopia: seismicity perspectives. J. Geophys. Res. 116.

Björnsson, A., 1985. Dynamics of crustal rifting in NE Iceland. J. Geophys. Res. 90 (B12), 10151-10162 Oct.

Björnsson, A., Saemundsson, K., Einarsson, P., Tryggvason, E., Grönvold, K., 1977. Current rifting episode in north Iceland. Nature 266, 318-323 Mar.

Brace, W.F., Kohlstedt, D.L., 1980. Limits on lithospheric stress imposed by laboratory experiments. J. Geophys. Res. 85, 6248-6252 Nov.

Brandsdóttir, B., Einarsson, P., 1979. Seismic activity associated with the September 1977 deflation of the Krafla central volcano in northeastern Iceland. J. Volcanol. Geotherm. Res. 6, 197-212 Nov.

Buck, W.R., 2006. The role of magma in the development of the Afro-Arabian Rift System. In: Yirgu, G., Ebinger, C.J., Maguire, P.K.H. (Eds.), The Afar Volcanic Province within the East African Rift System: Geological Society, Special Publications, London, 259, p. 43-43.

Buck, W.R., Lavier, L.L., Poliakov, A.N.B., 2005. Modes of faulting at mid-ocean ridges. Nature 434, 719-723 Apr..

Buck, W.R., Einarsson, P., Brandsdóttir, B., 2006. Tectonic stress and magma chamber size as controls on dike propagation: constraints from the 1975-1984 Krafla rifting episode. J. Geophys. Res. 111 (B10), 12404 Dec.

Byerlee, J.D., 1967. Frictional characteristics of granite under high confining pressure. J. Geophys. Res. 72, 3639-3648 Jul.

Byerlee, J.D., 1968. Brittle-ductile transition in rocks. J. Geophys. Res. 73, 4741-4750.

Byerlee, J.D., 1978. Friction of rocks. Pure Appl. Geophys. 116, 615-626.

Calais, E., D'Oreye, N., Albaric, J., Deschamps, A., Delvaux, D., Déverchère, J., Ebinger, C., Ferdinand, R.W., Kervyn, F., Macheyeki, A.S., Oyen, A., Perrot, J., Saria, E., Smets, B., Stamps, D.S., Wauthier, C., 2008. Strain accommodation by slow slip and dyking in a youthful continental rift, East Africa. Nature 456, 783-787 Dec.

Cannat, M., 1996. How thick is the magmatic crust at slow spreading oceanic ridges? J. Geophys. Res. 101, 2847-2858.

Cannat, M., Sauter, D., Mendel, V., Ruellan, E., Okino, K., Escartin, J., Combier, V., Baala, M., 2006. Modes of seafloor generation at a melt-poor ultraslow-spreading ridge. Geology 34, 605-608 Jul.

Chen, Y., Morgan, W.J., 1990. A nonlinear rheology model for mid-ocean ridge axis topography. J. Geophys. Res. 95, 17583-17604 Oct.

de Chabalier, J.-B., Avouac, J.-P., 1994. Kinematics of the Asal Rift (Djibouti) determined from the deformation of Fieale Volcano. Science 265, 1677-1681 Sep.

de Zeeuw-van Dalfsen, E., Pedersen, R., Sigmundsson, F., Pagli, C., 2004. Satellite radar interferometry 1993-1999 suggests deep accumulation of magma near the crust-mantle boundary at the Krafla volcanic system, Iceland. Geophys. Res. Lett. 31, 13611 Jul.

Dieterich, J.H., 1972. Time-dependent friction in rocks. J. Geophys. Res. 77, 3690-3697.

Doubre, C., Geoffroy, L., 2003. Rift-zone development around a plume-related magma centre on the Isle of Skye (Scotland): a model for stress inversions. Terra Nova $15,230-237$.

Doubre, C., Peltzer, G., 2007. Fluid-controlled faulting process in the Asal Rift, Djibouti, from 8 yr of radar interferometry observations. Geology 35, 69 Jan.

Doubre, C., Manighetti, I., Dorbath, C., Dorbath, L., Bertil, D., Delmond, J.-C., 2007a. Crustal structure and magmato-tectonic processes in an active rift (Asal-Ghoubbet, Afar, East Africa): 2. insights from the 23-year recording of seismicity since the last rifting event. J. Geophys. Res. 112 (B11), 5406 May.

Doubre, C., Manighetti, I., Dorbath, C., Dorbath, L., Jacques, E., Delmond, J.-C., 2007b. Crustal structure and magmato-tectonic processes in an active rift (Asal-Ghoubbet, Afar, East Africa): 1. insights from a 5-month seismological experiment. J. Geophys. Res. 112 (B11), 5405 May.

Dvorak, J.J., Okamura, A.T., 1987. A hydraulic model to explain variations in summit tilt rate at Kilauea and Mauna-Loa volcanoes. Volcanism in Hawaii: U. S. Geol. Surv. Prof. Pap., Vol. 1350, pp. 1281-1296.

Dziak, R.P., Smith, D.K., Bohnenstiehl, D.R., Fox, C.G., Desbruyeres, D., Matsumoto, H., Tolstoy, M., Fornari, D.J., 2004. Evidence of a recent magma dike intrusion at the slow spreading Lucky Strike segment, Mid-Atlantic Ridge. J. Geophys. Res. 109 (B18), 12102 Dec.

Ebinger, C.J., Keir, D., Ayele, A., Calais, E., Wright, T.J., Belachew, M., Hammond, J.O.S., Campbell, E., Buck, W.R., 2008. Capturing magma intrusion and faulting processes during continental rupture: seismicity of the Dabbahu (Afar) rift. Geophys. J. Int. 174, 1138-1152 Sep.

Ebinger, C.J., Ayele, A., Keir, D., Rowland, J., Yirgu, G., Wright, T.J., Belachew, M., 2010. Length and timescales of rift faulting and magma intrusion: the Afar rifting cycle from 2005 to present. Annu. Rev. Earth Planet. Sci. 38, 439-466 May.

Einarsson, P., Brandsdóttir, B., 1980. Seismological evidence for lateral magma intrusion during the July 1978 deflation of the Krafla volcano in NE-Iceland. J. Geophys. Res. 47, 160-165 Nov.

Escartín, J., Hirth, G., Evans, B., 1997. Effects of serpentinization on the lithospheric strength and the style of normal faulting at slow-spreading ridges. Earth Planet. Sci. Lett. 151, 181-189 Oct.
Ferguson, D.J., Barnie, T.D., Pyle, D.M., Oppenheimer, C., Yirgu, G., Lewi, E., Kidane, T. Carn, S., Hamling, I., 2010. Recent rift-related volcanism in Afar, Ethiopia. Earth Planet. Sci. Lett. 292 (3-4), 409-418 Apr.

Fialko, Y.A., Rubin, A.M., 1998. Thermodynamics of lateral dike propagation: implications for crustal accretion at slow spreading mid-ocean ridges. J. Geophys. Res. 103, 2501-2514 Feb.

Fialko, Y.A., Rubin, A.M., 1999. What controls the along-strike slopes of volcanic rift zones? J. Geophys. Res. 104, 20007-20020.

Fontaine, F.J., Cannat, M., Escartin, J., 2008. Hydrothermal circulation at slow-spreading mid-ocean ridges: the role of along-axis variations in axial lithospheric thickness. Geology 36, 759-762 Oct.

Gac, S., Geoffroy, L., 2009. 3D thermo-mechanical modelling of a stretched continental lithosphere containing localized low-viscosity anomalies (the soft-point theory of plate break-up). Tectonophysics 468, 158-168 Apr.

Garcia, S., Arnaud, N.O., Angelier, J., Bergerat, F., Homberg, C., 2003. Rift jump process in Northern Iceland since $10 \mathrm{Ma}$ from ${ }^{40} \mathrm{Ar} /{ }^{39} \mathrm{Ar}$ geochronology. Earth Planet. Sci. Lett. 214, 529-544 Sep.

Geoffroy, L., 2001. The structure of volcanic margins: some problematic from the North Atlantic/Labrador Baffin system. Mar. Pet. Geol. 18, 463-469.

Grandin, R., Socquet, A., Binet, R., Klinger, Y., Jacques, E., de Chabalier, J.B., King, G.C.P. Lasserre, C., Tait, S., Tapponnier, P., A.D, P.P., 2009. September 2005 Manda HararoDabbahu rifting event, Afar (Ethiopia): constraints provided by geodetic data. J. Geophys. Res. 114, B08404.

Grandin, R., Socquet, A., Doin, M.P., Jacques, E., De Chabalier, J.B., King, G.C.P., 2010a. Transient rift opening in response to multiple dike injections in the Manda Hararo rift (Afar, Ethiopia) imaged by time-dependent elastic inversion of interferometric synthetic aperture radar data. J. Geophys. Res. 115, B09403.

Grandin, R., Socquet, A., Jacques, E., Mazzoni, N., De Chabalier, J.B., King, G.C.P., 2010b. Sequence of rifting in Afar (Manda-Hararo rift, Ethiopia, 2005-2009): time-space evolution and interactions between dikes from InSAR and static stress change modeling. J. Geophys. Res. 115, B10413.

Grandin, R., Jacques, E., Nercessian, A., Ayele, A., Doubre, C., Socquet, A., Keir, D., Kassim, M., Lemarchand, A., King, G.C.P., 2011. Seismicity during lateral dike propagation: insights from new data in the recent Manda Hararo-Dabbahu rifting episode (Afar, Ethiopia). Geochem. Geophys. Geosyst. 12, Q04B08.

Gudmundsson, A., 1986. Formation of crustal magma chambers in Iceland. Geology 14 164 Feb.

Gudmundsson, A., 1990. Emplacement of dikes, sills and crustal magma chambers at divergent plate boundaries. Tectonophysics 176, 257-275 May.

Hamling, I.J., Ayele, A., Bennati, L., Calais, E., Ebinger, C.J., Keir, D., Lewi, E., Wright, T.J. Yirgu, G., 2009. Geodetic observations of the ongoing Dabbahu rifting episode: new dyke intrusions in 2006 and 2007. Geophys. J. Int. 178, 989-1003 Aug.

Hamling, I.J., Wright, T.J., Calais, E., Bennati, L., Lewi, E., 2010. Stress transfer between thirteen successive dyke intrusions in Ethiopia. Nat. Geosci. 3, 713-717 Oct.

Harper, G.D., 1985. Tectonics of slow spreading mid-ocean ridges and consequences of a variable depth to the brittle/ductile transition. Tectonics 4, 395-409.

Hayward, N.J., Ebinger, C.J., 1996. Variations in the along-axis segmentation of the Afar Rift system. Tectonics 15, 244-257.

Hirth, G., Escartín, J., Lin, J., 1998. The rheology of the lower oceanic crust: implications for lithospheric deformation at mid-ocean ridges. In: Buck, R. (Ed.), Faulting and Magmatism at Mid-Ocean Ridges. : AGU Geophysical Monograph 106. AGU, pp. 291-303.

Ida, Y., 1999. Effects of the crustal stress on the growth of dikes: conditions of intrusion and extrusion of magma. J. Geophys. Res. 104, 17897-17910 Aug.

Keir, D., Ebinger, C.J., Stuart, G.W., Daly, E., Ayele, A., 2006. Strain accommodation by magmatism and faulting as rifting proceeds to breakup: seismicity of the northern Ethiopian rift. J. Geophys. Res. 111 (B10), 5314 May.

Keir, D., Hamling, IJ., Ayele, A., Calais, E., Ebinger, C., Wright, T., Jacques, E., Mohamed K., Hammond, J.O.S., Belachew, M., Baker, E., Rowland, J., Lewi, E., Bennati, L., 2009. Evidence for focused magmatic accretion at segment centers from lateral dike injections captured beneath the Red Sea rift in Afar. Geology 37 (1), 59-62 Jan.

Keir, D., Pagli, C., Bastow, I., Ayele, A., 2011. The magma-assisted removal of Arabia in Afar: evidence from dike injection in the Ethiopian rift captured using InSAR and seismicity. Tectonics 30, TC2008.

Kohlstedt, D.L., Goetze, C., 1974. Low-stress high-temperature creep in olivine single crystals. J. Geophys. Res. 79, 2045-2051.

Kong, L.S.L., Solomon, S.C., Purdy, G.M., 1992. Microearthquake characteristics of a Midocean Ridge along-axis high. J. Geophys. Res. 97, 1659-1685 Feb.

Kuo, B., Forsyth, D.W., 1988. Gravity anomalies of the ridge-transform system in the South Atlantic between 31 and $34.5^{\circ} \mathrm{S}$ : upwelling centers and variations in crustal thickness. Mar. Geophys. Res. 10, 205-232 Sep.

Lachenbruch, A.H., 1961. Depth and spacing of tension cracks. J. Geophys. Res. 66, 4273-4292 Dec.

Lagabrielle, Y., Bideau, D., Cannat, M., Karson, J.A., Mével, C., 1998. Ultramafic-mafic plutonic rock suites exposed along the Mid-Atlantic Ridge $\left(10^{\circ} \mathrm{N}-30^{\circ} \mathrm{N}\right)$ : symmetrical-asymmetrical distribution and implications for seafloor spreading. In: Buck R. (Ed.), Faulting and Magmatism at Mid-Ocean Ridges. : AGU Geophysical Monograph 106. AGU, pp. 153-176.

Lahitte, P., Gillot, P.-Y., Courtillot, V., 2003. Silicic central volcanoes as precursors to rift propagation: the Afar case. Earth Planet. Sci. Lett. 207, 103-116 Feb.

Lin, J., Purdy, G.M., Schouten, H., Sempere, J.-C., Zervas, C., 1990. Evidence from gravity data for focused magmatic accretion along the Mid-Atlantic Ridge. Nature 344, 627-632 Apr.

Lister, J.R., Kerr, R.C., 1991. Fluid-mechanical models of crack propagation and their application to magma transport in dykes. J. Geophys. Res. 96, 10049-10077 Jun.

MacDonald, K.C., Scheirer, D.S., Carbotte, S.M., 1991. Mid-ocean ridges - discontinuities, segments and giant cracks. Science 253, 986-994 Aug. 
Magde, L.S., Sparks, D.W., Detrick, R.S., 1997. The relationship between buoyant mantle flow, melt migration, and gravity bull's eyes at the Mid-Atlantic Ridge between $33^{\circ} \mathrm{N}$ and $35^{\circ} \mathrm{N}$. Earth Planet. Sci. Lett. 148, 59-67.

Makris, J., 1987. The Afar depression: transition between continental rifting and seafloor spreading. Tectonophysics 141, 199-214 Sep.

Manighetti, I., Tapponnier, P., Gillot, P.-Y., Jacques, E., Courtillot, V., Armijo, R., Ruegg, J.-C., King, G.C.P., 1998. Propagation of rifting along the Arabia-Somalia plate boundary: into Afar. J. Geophys. Res. 103 (B3), 4947-4974 Mar.

Manighetti, I., Tapponnier, P., Courtillot, V., Gallet, Y., Jacques, E., Gillot, P.-Y., 2001. Strain transfer between disconnected, propagating rifts in Afar. J. Geophys. Res. $106,13613-13666$

McGarr, A., Spottiswoode, S.M., Gay, N.C., Ortlepp, W.D., 1979. Observations relevant to seismic driving stress, stress drop, and efficiency. J. Geophys. Res. 84, 2251-2261 May.

Neumann, G.A., Forsyth, D.W., 1993. The paradox of the axial profile: isostatic compensation along the axis of the Mid-Atlantic Ridge. J. Geophys. Res. 98, 17891-17910 Oct.

Owen, S., Segall, P., Lisowski, M., Miklius, A., Murray, M., Bevis, M., Foster, J., 2000. January 30, 1997 eruptive event on Kilauea Volcano, Hawaii, as monitored by continuous GPS. Geophys. Res. Lett. 27, 2757-2760 Sep.

Pallister, J.S., McCausland, W.A., Jónsson, S., Lu, Z., Zahran, H.M., Hadidy, S.E., Aburukbah, A., Stewart, I.C.F, Lundgren, P.R., White, R.A, Moufti, M.R.H., 2010. Broad accommodation of rift-related extension recorded by dyke intrusion in Saud Arabia. Nat. Geosci. 3, 705-712 Oct.

Paquet, F., Dauteuil, O., Hallot, E., Moreau, F., 2007. Tectonics and magma dynamics coupling in a dyke swarm of Iceland. J. Struct. Geol. 29, 1477-1493 Sep.

Parsons, T., Thompson, G.A., 1991. The role of magma overpressure in suppressing earthquakes and topography: worldwide examples. Science 253, 1399-1402 Sep.

Pedersen, R., Sigmundsson, F., Masterlark, T., 2009. Rheologic controls on inter-rifting deformation of the Northern Volcanic Zone, Iceland. Earth Planet. Sci. Lett. 281, 14-26 Apr.

Phipps Morgan, J., Parmentier, E.M., Lin, J., 1987. Mechanisms for the origin of Mid-Ocean Ridge axial topography: implications for the thermal and mechanica structure of accreting plate boundaries. J. Geophys. Res. 92, 12823-12836 Nov.

Pinel, V., Jaupart, C., 2004. Magma storage and horizontal dyke injection beneath a volcanic edifice. Earth Planet. Sci. Lett. 221, 245-262 Apr.

Pinzuti, P., Mignan, A., King, G. C. P., 2010. Surface morphology of active normal faults in hard rock: implications for the mechanics of the Asal Rift, Djibouti. In proof reading, EPSL.

Poliakov, A.N.B., Buck, R.W., 1998. Mechanics of stretching elastic-plastic-viscous layers: applications to slow-spreading mid-ocean ridges. In: Buck, R. (Ed.), Faulting and Magmatism at Mid-Ocean Ridges. : AGU Geophysical Monograph 106. AGU, pp. 305-323.

Pollard, D.D., Segall, P., 1987. Fracture mechanics of rock. In: Atkinson, B.K. (Ed.), Theoretical Displacements and Stresses near Fractures in Rock: with Applications to Faults, Joints, Veins, Dikes, and Solution Surfaces. Academic Press, pp. 277-349. Ch.

Pollard, D.D., Delaney, P.T., Duffield, W.A., Endo, E.T., Okamura, A.T., 1983. Surface deformation in volcanic rift zones. Tectonophysics 94 (1-2), 541-584.

Qin, R., Buck, W.R., 2008. Why meter-wide dikes at oceanic spreading centers? Earth Planet. Sci. Lett. 265, 466-474 Jan.

Rabain, A., Cannat, M., Escartín, J., Pouliquen, G., Deplus, C., Rommevaux-Jestin, C. 2001. Focused volcanism and growth of a slow spreading segment (Mid-Atlantic Ridge, $35^{\circ} \mathrm{N}$ ). Earth Planet. Sci. Lett. 185, 211-224 Feb.

Rivalta, E., 2010. Evidence that coupling to magma chambers controls the volume history and velocity of laterally propagating intrusions. J. Geophys. Res. 115, B07203. doi:10.1029/2009JB006922.

Rowland, J.V., Baker, E., Ebinger, C.J., Keir, D., Kidane, T., Biggs, J., Hayward, N., Wright T.J., 2007. Fault growth at a nascent slow-spreading ridge: 2005 Dabbahu rifting episode, Afar. Geophys. J. Int. 171 (10), 1226-1246 Dec.
Rubin, A.M., 1990. A comparison of rift-zone tectonics in Iceland and Hawaii. Bull. Volcanol. 52, 302-319 Mar.

Rubin, A.M., 1992. Dike-induced faulting and graben subsidence in volcanic rift zones. J. Geophys. Res. 97 (B2), 1839-1858 Feb.

Rubin, A.M., 1995. Propagation of magma-filled cracks. Annu. Rev. Earth Planet. Sci. 23, 287-336.

Rubin, A.M., Pollard, D.D., 1987. Origins of blade-like dikes in volcanic rift zones. In: Decker, R.W., Wright, T.L., Stauffer, P.H. (Eds.), Volcanism in Hawaii: U.S. Geological Survey Professional Paper. U.S. Geological Survey, Ch. 53, Vol. 1350, pp. 1449-1470.

Ruegg, J.-C., Kasser, M., Lépine, J.-C., Tarantola, A., 1979. Geodetic measurements of rifting associated with a seismo-volcanic crisis in afar. Geophys. Res. Lett. 6 (11), 817-820.

Ryan, M.P., 1993. Neutral buoyancy and the structure of mid-ocean ridge magma reservoirs. J. Geophys. Res. 98, 22321-22338 Dec.

Sempéré, J., Lin, J., Brown, H.S., Schouten, H., Purdy, G.M., 1993. Segmentation and morphotectonic variations along a slow-spreading center: the Mid-Atlantic Ridge $\left(24^{\circ} 00^{\prime} \mathrm{N} 30^{\circ} 40^{\prime} \mathrm{N}\right)$. Mar. Geophys. Res. 15, 153-200 Aug.

Shaw, P.R., 1992. Ridge segmentation, faulting and crustal thickness in the Atlantic Ocean. Nature 358, 490-493 Aug.

Shaw, W.J., Lin, J., 1996. Models of ocean ridge lithospheric deformation: dependence on crustal thickness, spreading rate, and segmentation. J. Geophys. Res. 101, 17977-17994 Aug.

Sicilia, D., Montagner, J.-P., Cara, M., Stutzmann, E., Debayle, E., Lépine, J.-C., Lévêque, J.-J., Beucler, E., Sebai, A, Roult, G., Ayele, A, Sholan, J.M. 2008. Upper mantle structure of shear-waves velocities and stratification of anisotropy in the Afar Hotspot region. Tectonophysics 462, 164-177 Dec.

Smith, D.K., Cann, J.R., 1999. Constructing the upper crust of the Mid-Atlantic Ridge: a reinterpretation based on the Puna Ridge, Kilauea Volcano. J. Geophys. Res. 104, 25379-25400 Nov.

Speight, J., Skelhorn, R., Sloan, T., Knaap, R., 1982. The dyke swarms of Scotland. In: Sutherland, D.S. (Ed.), Igneous Rocks of the British Isles. Wiley, New-York, pp. 449-621.

Spence, D.A., Turcotte, D.L., 1985. Magma-driven propagation of cracks. J. Geophys. Res. 90, 575-580 Feb.

Tapponnier, P., Francheteau, J., 1978. Necking of the lithosphere and the mechanics of slowly accreting plate boundaries. J. Geophys. Res. 83, 3955-3970 Aug.

Thibaud, R., Dauteuil, O., Gente, P., 1999. Faulting pattern along slow-spreading ridge segments: a consequence of along-axis variation in lithospheric rheology. Tectonophysics 312, 157-174 Nov.

Tiberi, C., Ebinger, C., Ballu, V., Stuart, G., Oluma, B., 2005. Inverse models of gravity data from the Red Sea-Aden-East African rifts triple junction zone. Geophys. J. Int. 163, 775-787 Nov.

Turcotte, D.L., Schubert, G., 2002. Geodynamics, Second Edition. Cambridge University Press, Cambridge.

Wada, Y., 1994. On the relationship between dike width and magma viscosity. J. Geophys. Res. 99, 17743-17755 Sep.

Walker, G.P.L., 1987. The dike complex of Koolau Volcano, Oahu: internal structure of an Hawaiian rift zone. Volcanism in Hawaii: U. S. Geol. Surv. Prof. Pap., Vol. 1350, pp. 961-993.

Walter, T.R., Troll, V.R., Cailleau, B., Belousov, A., Schmincke, H.-U., Amelung, F., Bogaard, P., 2005. Rift zone reorganization through flank instability in ocean island volcanoes: an example from Tenerife, Canary Islands. Bull. Volcanol. 67, 281-291 Apr.

Weertman, J., 1971. Theory of water-filled crevasses in glaciers applied to vertical magma transport beneath oceanic ridges. J. Geophys. Res. 76 (5), 1171-1183.

Wright, T.J., Ebinger, C., Biggs, J., Ayele, A., Yirgu, G.J., Keir, D., Stork, A., 2006. Magmamaintained rift segmentation at continental rupture in the 2005 Afar dyking episode. Nature 442, 291-294 Jul. 